$11^{6}$

(3)

in

vit

ve

\title{
HAND CALCULATOR PROGRAMS \\ FOR WEAPONS EFFECTS ANALYSES - \\ THE PHYSICAL VULNERABILITY SYSTEM
}

Vaughn E. Culler

August 3, 1976

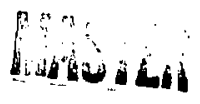

Prepared for U.S. Energy Research \& Development

Administration under contract No. W-7405-Eng-48

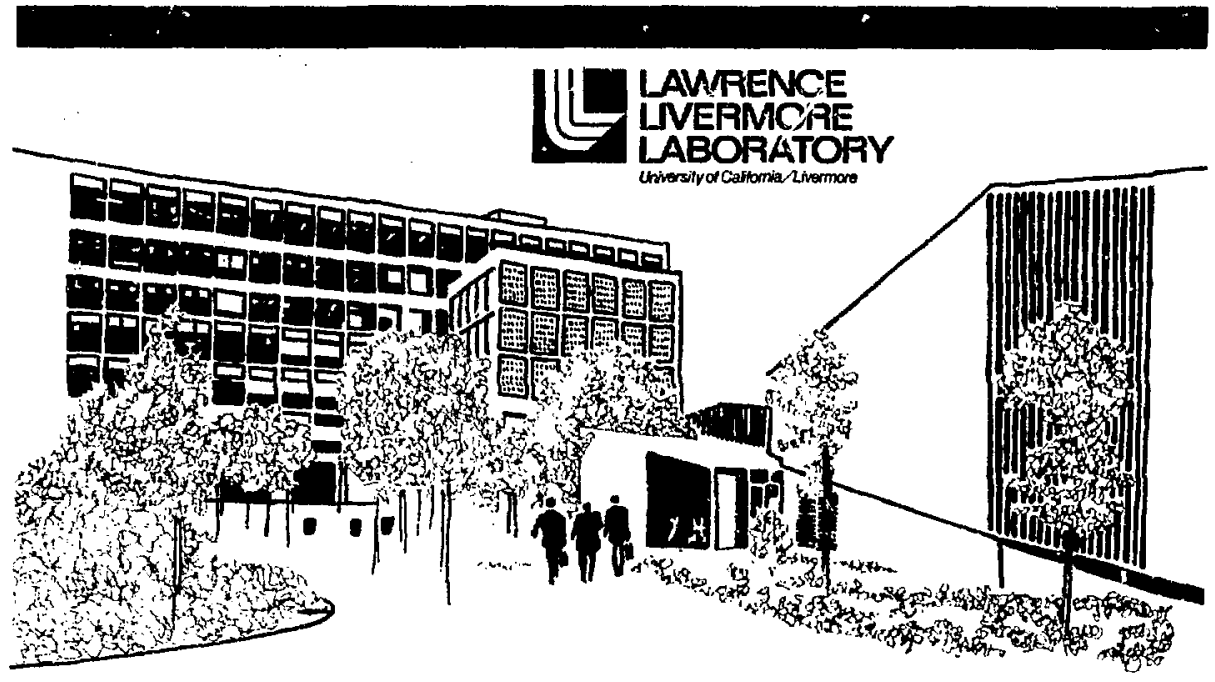

$-$ 


\title{
NOTICE
}

This nport was prepered 0 an cceount of work poneored by the United Sutes Gowemnent. Neithen the Untied States nor the Unitod Srater Energy Rewerch - Dewlopment Adminiantion, nor ny of their employws, nor eny of their contractors, enbcontesters, of the ir imployets, neskel any warrenty, exprese of unplad, or awmms any leal !ibblity of retponsiblity for the ecurncy, completentas of usfulnow of any information, appinatus product of proces dicelond, of represunts that ils us would not infringe privatuly-owned thents.

\section{MOTICE}

Reference to company of product nume does nol imply upproval or mecommendation of the product by the Untretally of Culfornia of the U.S. Enescy Reswuch a Dewelopment Administration to the exclusion of okers that mas on aitible.

\author{
Pinted in the Uniled States of Americe \\ Avallabie from \\ National Technical Information Servise \\ U.S. Department of Commerce \\ 5285 Port Royal Road \\ Springineld, VA 22161 \\ Price: Printed Copy $\$$ : Microfiche 52.25
}

\begin{tabular}{|c|c|c|c|}
\hline Purs Rene & $\begin{array}{c}\text { Dombite } \\
\text { Prles }\end{array}$ & Pas Rans & $\begin{array}{c}\text { Domertie } \\
\text { Pripe }\end{array}$ \\
\hline $001-025$ & s 3.50 & $326-350$ & 10.00 \\
\hline $026-050$ & 4.00 & $351-375$ & I1) SO \\
\hline $051-075$ & 4.50 & $376-400$ & 10.75 \\
\hline $076-100$ & 5.00 & $401-425$ & 11.00 \\
\hline $101-125$ & 5.50 & $426-450$ & 11.75 \\
\hline $126-150$ & 6.00 & $451-475$ & 12.00 \\
\hline $151-175$ & 6.75 & $476-500$ & 1250 \\
\hline $176-200$ & 7.50 & $501-525$ & 12.75 \\
\hline $201-225$ & 7.75 & $526-550$ & . 3.00 \\
\hline $226-250$ & 8.00 & $551-575$ & $\$ 3.50$ \\
\hline $251-275$ & 9.00 & $576-600$ & 13.75 \\
\hline $276-300$ & 9.25 & $601-$ up & $\bullet$ \\
\hline $301-325$ & 9.75 & & \\
\hline
\end{tabular}

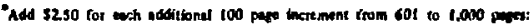
w4 4.50 fot each selditoal 180 pere inctement ont 1,000 meth 


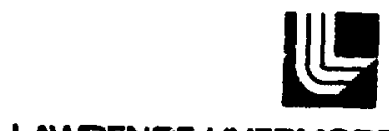

LAWRENCE I.NERMORE LABORATORY

Universilyot Cavorna Livermoro Catioma 94550

\title{
UะRL-52103 \\ HAND CALCULATOR PROGRAMS FOR WEAPONS EFFECTS ANALYSES - THE PHYSICAL VULNERABILITY SYSTEM
}

\author{
Vaughn E. Culler
}

MS. date: August 3,1976

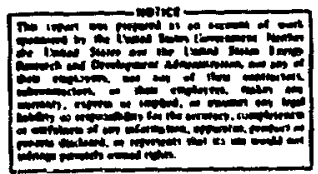




\section{Contents}

Ahserait.

Int roduction

Prop;rimsi

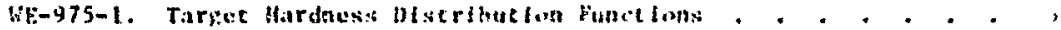

WB-975-2. Heteralnation of idjusted fulneriblliey

Nuabers for P'type Toritots . . . . . . . . . . . .

Wh-975-3. Peak overprossoures and Ndusted fulforablizy

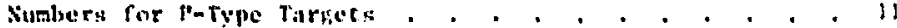

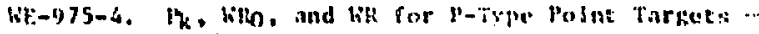

sarface burat . . . . . . . . . . . . . . . 1.

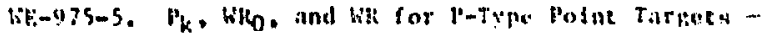

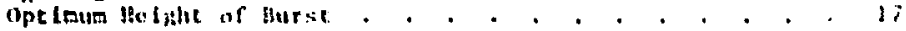

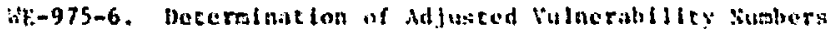

for o-type Targecs . . . . . . . . . . . . . . .

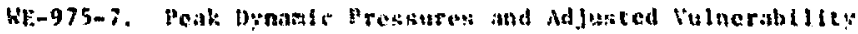

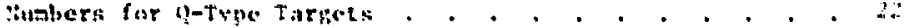

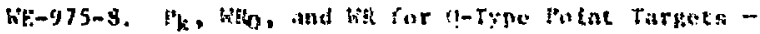

stirlace burke . . . . . . . . . . . . . . . 2j

HF-975-9. Ovorpressuro or Dynale prosistore from the

Adjusted vulnerability suaber . . . . . . . . . . 2 .

ni-975-10. "Eex", Overpressure diven Yleld and hange ro:

Surfarc Burse and figeo Air Burat . . . . . . . . . II

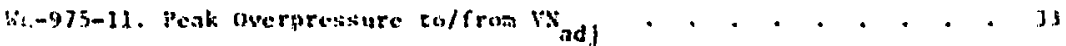

We-975-12. Peak Dynade Pressure to/from is ad . . . . . . . . W 


\title{
HAND CALCULATOR PROGRAMS \\ FOR WEAPONS EFFECTS ANALYSES - \\ THE PHYSICAL VULNERABILITY SYSTEM
}

\begin{abstract}
The plysical vulnerablitey systom for evaluacing frobable damage from a nuclear bhase has recelved wide acceptance hecause it is a simple but general systen appliatile to a wide variety of target classes. We describe here a actes of hand-ablculator proprins using this system that permite equally A curate but fattor calculations than ehe conventlonal handhook method. The

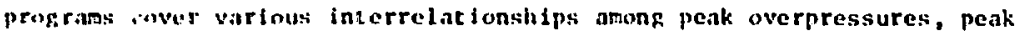
dynafle pressures, vulnerabilicy mubers, weapons radif, and klll probability.

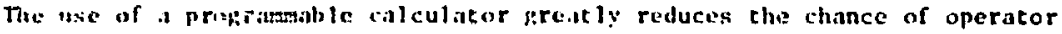
vrrur by el itinating individual hand calculations and graphical determinations of paramezer values.
\end{abstract}

\section{Introduction}

Auclear-bla:s damafe evaluat lons are usually prepared from a variety of kriapiss, nopostaphs, tables, and hand calculations. 1 opportunities for error abound. Cross checks are elther difficule or impossible. The tedium of a parameter seudy cin be oncrous; one of ten tries to lessen the burden by making singlifying approximat funs that can sometimes lead to erroneous conclusions.

He have found that exploltation of the capabilicies of a programmable calculator - in our cise, the llewlett-Packard ItP-65 - Ieads to faster, more accuratc calculacions with fewer operator error. A cenfold, cven hundredfold, increase in speed th often attainable. In Table 1 we 1 tst the titles of some weapons cffects programs we have developed for the HP-65. The symbollsm, basically that of Hef. I, Is explatined in the individual programs. In Table 2 we five the Input parameters, the output (what is calculated), and the cypical running time for each progatin.

The balance of this document is given over to the individual programs. E.ach is presented in the sane format: a short description, then user instructions, example(s) of use, and finally a program listing that can be recorded 
Tabie 1. Weapons effects programs for the HP-65.

\begin{tabular}{|c|c|}
\hline $\begin{array}{l}\text { Program } \\
\text { number }\end{array}$ & Title \\
\hline WE-975-1 & Target Ha:dness Distrlbution Functions \\
\hline WE- $975-2$ & $\begin{array}{l}\text { Determination of Adjusted Vulnerability Numbers for } \\
\text { P-Type Targets }\end{array}$ \\
\hline WE- $975-3$ & $\begin{array}{l}\text { Peak Overpressures and Adfusted Vulnerability Numbers ior } \\
\text { P-Type Targets }\end{array}$ \\
\hline WE-975-4 & $P_{k}, W E_{0}$, and $W R$ for P-Type Point Targets - Surface Burst \\
\hline WE-975-5 & $\begin{array}{l}P_{k}, W E_{0} \text {, and WR for P-Type Point Targets - Optinum } \\
\text { Helght cf Burst }\end{array}$ \\
\hline WE-975-6 & $\begin{array}{l}\text { Determination of Adjusted Vulnerability Numbers for Q-Type } \\
\text { Targets }\end{array}$ \\
\hline WE-975-7 & $\begin{array}{l}\text { Peak Dynamic Pressures and Adjusted Vulnerability Numbers } \\
\text { for Q-Type Targets }\end{array}$ \\
\hline WE-975- 3 & $P_{k}, W_{0}$, and WR for Q-Type Point Targets - Surface Burst \\
\hline WE-975-9 & $\begin{array}{l}\text { Overpressure or Dynamic Pressure from the Adjusted } \\
\text { Vulnerability Number }\end{array}$ \\
\hline WE-975-10 & $\begin{array}{l}\text { Peak Overpressure Glven Yleld and Range for Surface Burst } \\
\text { or Free Air Burst }\end{array}$ \\
\hline WE-975-11 & Peak Overpressure to/f rom $\mathrm{WN}_{\text {ad }}$ \\
\hline WE-975-12 & Peak Dynamic Pressure to/from VN ${ }_{\text {adj }}$ \\
\hline
\end{tabular}

on a program card. The categorizing number system for the programs is somewhat arbitrary: first, chere are identiflers WE (for Weapons Ef fects) and 975 (September 1975) to date the program, tisen there is a cardinal number to distinguish each program from others of the sarv: famfly and age.

Because the procedures for weapons effects analyses have not yet been metricated, we retain English units in the programs but do include sI units if calculator memory is large enough to permit their inclusion. The trend is toward larger memories which, when avallable, will permit the use of either type units with very simple modifications. Many of the programs have been destgned with the transition to more powerful calculators in mind. For example, input parameters and calculated results are stored in memory whenever convenientiy possible. 
Table 2. Input parameters, outputs (what is calculated), and cypical running times of weapons effects programs.

\begin{tabular}{|c|c|c|c|}
\hline $\begin{array}{l}\text { Program } \\
\text { number }\end{array}$ & Input & Output & $\begin{array}{l}\text { Typical } \\
\text { rut ning } \\
\text { time, s }\end{array}$ \\
\hline WE-975-1 & $p$ and $p_{0.5}$ or $q$ and $q_{0.5}$ & $r_{k}$ & 15 \\
\hline WE-975-2 & $\mathrm{VN}_{0}: \mathrm{K}, \mathrm{W}$ & $\mathrm{VN}_{\text {adj }}$ & $\therefore 10$ \\
\hline WE-975-3 & $\mathrm{VN}_{0}, \mathrm{~K}, \mathrm{~W}$ & $p, V N w_{\text {adj }}$ & 10 \\
\hline WE-975-4 & $\begin{array}{l}V N_{\text {adj }} \text { and } W \text { (elther entered } \\
\text { direct } 1 \text { y or from WE-975-2 } \\
\text { or }-11 \text { ), CEP }\end{array}$ & $\begin{array}{l}P_{k}, W R_{0}, W R \\
\text { (surfuce bur't) }\end{array}$ & $<10$ \\
\hline WE-975-5 & $\begin{array}{l}V N_{\text {adj }} \text { and } W \text { (elther entered } \\
\text { directly or from }(\mathrm{we}-975-2) \text {, } \\
\text { CEP }\end{array}$ & $\begin{array}{l}P_{k}, W_{0}, W R \\
(\text { optimum HOB })\end{array}$ & $<10$ \\
\hline WE-975-6 & $W N_{0}, K, W$ & vis & 15 \\
\hline WE-975-7 & $v N_{0}, K, w$ & $q, v_{\text {adj }}$ & 20 \\
\hline WE-975-8 & $\begin{array}{l}V N_{\text {adf }} \text { and } W \text { (either entered } \\
\text { directly or from WE-975-6 } \\
\text { or }-12 \text { ), CEP }\end{array}$ & $\begin{array}{l}P_{k}, W_{0}, \text { WR } \\
\text { (surface burst) }\end{array}$ & $<10$ \\
\hline WE-975-9 & $\begin{array}{l}\text { P-type VN adj or } \\
\text { q-type } V N_{\text {adj }}\end{array}$ & $p$ or $q$ & $<5$ \\
\hline WE-975-10 & $W, R$ & $\mathbf{p}$ & 5 \\
\hline WE-975-11 & $\mathrm{VN}_{\text {adj }}$ or $\mathrm{p}$ & $p$ or $\mathrm{VN}_{\text {adj }}$ & $<5$ \\
\hline WE-975-12 & WN $_{\text {adj }}$ or 9 & $q$ or $\mathrm{WN}_{\text {adf }}$ & $<5$ \\
\hline
\end{tabular}

The programs with the longer running times harje the comnon characteristic of using inefficient iterations, because of limited calculator memory. The cholce of inefficient iterations over approximations of limited range or accuracy was deliberate; even the longest program has a typical running time of only $20 \mathrm{~s}$, iterations and all.

Although we do not know of any "bugs" In the programs, we cannot guarantee there are none. If any are discovered, we would aprreciate hearing about them. 
Washing of hands - an author's caveat! These programs were wricten In self-defense. I need to speak the "Iingo" of the physical vulnerability system and to understand what others were saying when that lingo was used. Use the programs as tools, not as oracles!

\section{Programs}

Our weapons effects programs for the HP-65 arc described on the following pages. 
PROCRAM UE-975-1. TAPGET HARWNESS DISTRIBUTION FUNCTIONS

\section{Description}

A fundamental requirement of any handbook-type treatment of blast effects is that the effects must be calculable for a wide range of target types.

T: meet this requirement, the physicial vulnerability system is based on likelibud or irobability that a spectfied level of damage to a given class of itructures can nften be described by a lognormal distribution of peak overpressure or peak dynamic pressure. Thus, the same types of equations, but with different constanls, apply to a :lde range of different target classes.

For "l-type" targets - those vulnerable primarlly to peak overnressure (p) - the lomormal distribution describing the expected damage is

$$
F(r, w)=\frac{1}{\sqrt{2^{+}}} \int_{-\infty}^{z} e^{-t^{2} / 2} d t
$$

where $F(, \cdot k)$ is the probibility that $a$ target selected at random from the poptintion will havi a hlast hardness less than or equal to $p$ for a nuclear exolosion of $\because$ icld k $^{\prime}$ and for $z$ given by

$$
\left.z=\frac{1}{a} \ln (p / p) .5\right) \text {. }
$$

Note shat $p_{0.5}$ is the value of $p$ for which $F(p, W)$ is equal to $1 / 2$.

One of the great generalizations of the physical vulnerabllicy system for nuclear weapon - is that, for every class of targets vulnerable to peak overpressure, $a_{p}$ has the sqme value. A second graat generalization is that the same types of relitclons hold for "Q-type" targets - those vulnerable to peak dynauis pressur - (q) - and that the corresponding $\alpha_{q}$ also has the sane value for every, class of such targets.

We therefore describe all zeak-overpressure targets by Eqs. (1) and (2) or, in differential form,

$$
f(p, w)=\frac{d F(p, w)}{d x}=\frac{1}{\sqrt{2 \pi} \alpha_{p}} e^{-x^{2} / 2 \alpha_{p}^{2}},
$$


where $x=\ln \left(p / p_{0.5}\right)$ and $f(p, w)$ is interpreted as a probability density function. Thus $f(p, W) d x$ is the probability that a tarpet selected at random will have a hardness in the logarithmic increment $x$ to $x+d x$.

Eyuations formally ddentical to (1), (2), and (j) apply for (0-type targets $1 \pi$ that $q, q_{0.5}$ and $\alpha_{q}$ replace $p, p_{0.5}$, and $q_{p}$ :

$$
\begin{aligned}
& F(q, W)=\frac{1}{\sqrt{2 \pi}} \int_{-\infty}^{z} e^{-t^{2} / 2} d t ; \\
& \therefore=\frac{1}{\alpha_{\eta}} \ln \left(q / q_{0,5}\right) ; \\
& f(-1, W)=\frac{d F(a, \omega)}{d x}=\frac{1}{\sqrt{2 \pi} \alpha_{q}} e^{-x^{2} ! 2 \alpha_{q}^{2}},
\end{aligned}
$$

where $x=\ln \left(q / q_{0.5}\right)$.

This program calculates $f$ and $F$ for either P-type or Q-type targets as functions of either $F$ (given $p_{0.5}$ ) or $q$ (given $q_{0.5}$ ). The constants $\alpha_{p}=0.29718$ ard $\alpha_{q}=1.0419$ are contained in the program. The approprlate one is generated in a preliminary operation. Once $\alpha_{p}$ or $\alpha_{q}$ fs selected, there are some built-in constrafn.s that sep the proper vail locked into the program and hence tamperproof to any but a deliberate change. The results

\begin{tabular}{|c|c|c|c|c|}
\hline Step & $\begin{array}{c}\text { Insiructions/ } \\
\text { comments }\end{array}$ & $\begin{array}{c}\text { Input } \\
\text { data/units }\end{array}$ & Key & $\begin{array}{c}\text { Output } \\
\text { data/units }\end{array}$ \\
\hline 1 & Eriter program. & & & \\
\hline \multirow[t]{7}{*}{2} & Preliminary calculation: & & & \\
\hline & for P-type & & $\mathbf{L}$ & $\alpha_{p} / 0.30$ \\
\hline & for Q-type & & $\mathbf{E}$ & $\alpha_{q} / 1.04$ \\
\hline & The remaining instructions are & & & \\
\hline & for a P-type calculation. A & & & \\
\hline & Q-type vould be identical exrept & & & \\
\hline & $q$ would appear instead of $p$. & & & \\
\hline 3 & Enter $P$. & & A & $\mathbf{p}$ \\
\hline 4 & Enter $p_{0.5}$, calculate $f(p, W)$ & & $\mathrm{R} / \mathrm{S}$ & $f(P, W)$ \\
\hline
\end{tabular}
are calculated correctly to at least three significivi: figures.

\section{User Instructions}


Vsers Instructions (Cont.)

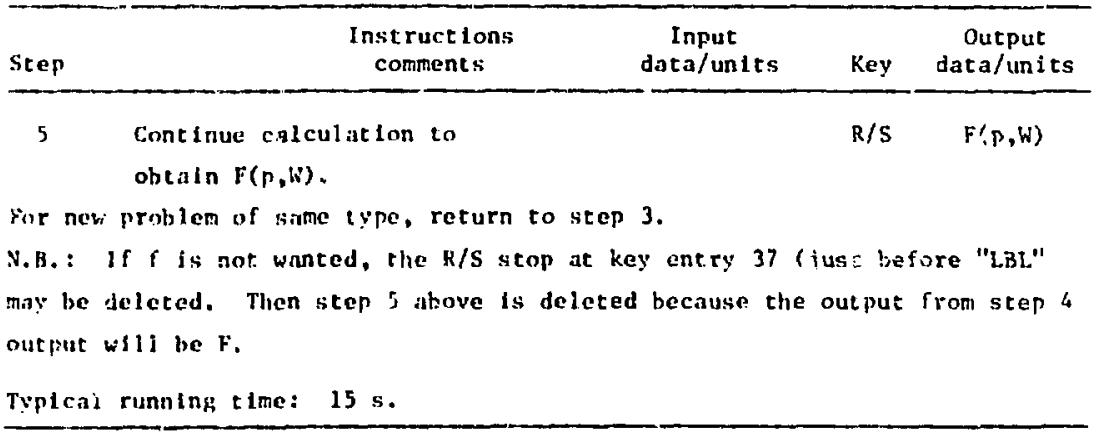

\section{Example}

it a given yield. $p_{0.5}$ is $75 \mathrm{nsl}$. What fraction of the same type targets wulu be expected to be damaged at last to the same characteristle level if $\mathrm{p}$ were $150 \mathrm{psi}$ ? $90 \mathrm{psi}$ ?

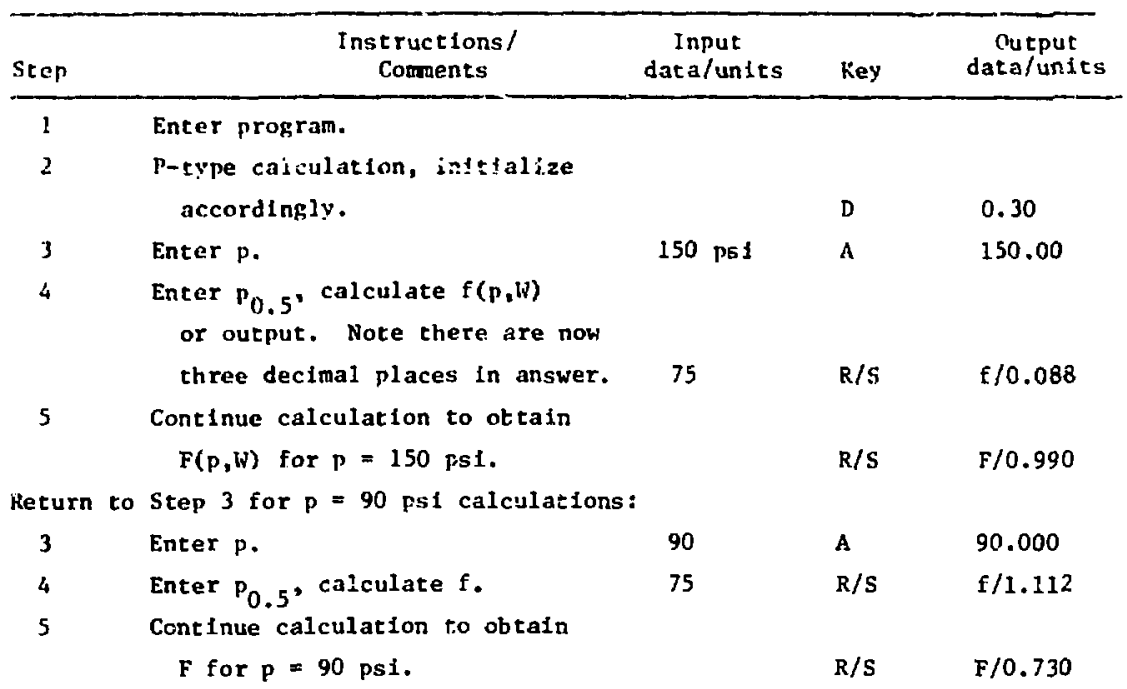

Answer: For $\mathrm{p}=150 \mathrm{ps} 1,99.0 \%$; for $\mathrm{p}=90 \mathrm{ps} 1,73.0 \%$. 
Program WE-975-I Listing

\begin{tabular}{|c|c|c|c|c|c|c|c|c|c|c|}
\hline \multirow{2}{*}{$\begin{array}{c}\begin{array}{c}\text { Key } \\
\text { entry }\end{array} \\
\text { LBL }\end{array}$} & $\begin{array}{l}\text { Code } \\
\text { shown }\end{array}$ & \multirow{2}{*}{$\frac{\begin{array}{c}\text { Key } \\
\text { entry }\end{array}}{\div}$} & \multicolumn{2}{|c|}{$\begin{array}{r}\text { Code } \\
\text { shown }\end{array}$} & \multirow{2}{*}{$\begin{array}{c}\begin{array}{c}\text { Key } \\
\text { entry }\end{array} \\
\text { RCL } 4\end{array}$} & \multicolumn{2}{|c|}{$\begin{array}{r}\text { Code } \\
\text { shown }\end{array}$} & \multicolumn{2}{|c|}{$\begin{array}{c}\text { Key } \\
\text { entry }\end{array}$} & $\begin{array}{r}\text { Code } \\
\text { shown }\end{array}$ \\
\hline & 23 & & & $B 1$ & & 34 & 04 & 0 & & 00 \\
\hline A & 11 & $f$ & & 31 & $x$ & & 71 & 4 & & 04 \\
\hline$\uparrow$ & 41 & $\sqrt{x}$ & & 09 & RCL 7 & 34 & 07 & 1 & & 01 \\
\hline$R / S$ & 84 & sTo 4 & 33 & 04 & $\mathrm{x}$ & & 71 & 9 & & 09 \\
\hline$\div$ & 81 & RCL 5 & 34 & 05 & . & & 83 & STO & 33 & 3305 \\
\hline I & 31 & $\div$ & & 81 & 5 & & 05 & RI'N & & 24 \\
\hline IN & 07 & $R / S$ & & 84 & $\div$ & & 61 & GTO & & 22 \\
\hline $\mathrm{RCL} 5$ & 3405 & LBL & & 23 & RTN & & 24 & $\mathrm{E}$ & & 15 \\
\hline$:$ & $B 1$ & 1 & & 01 & LBI. & & 2.3 & & & \\
\hline DSP & 21 & RCL I & 34 & 01 & B & & 12 & & & \\
\hline - & 83 & RCL 3 & 34 & 03 & 0 & & 00 & & & \\
\hline 3 & 03 & $\div$ & & 81 & $\mathrm{R} / \mathrm{S}$ & & 84 & & & \\
\hline STO 7 & 3307 & RCL 6 & 34 & 06 & GTO & & 22 & & & \\
\hline$\uparrow$ & 41 & $x$ & & 71 & B & & 12 & & & \\
\hline $\mathrm{x}$ & 71 & STO 6 & 33 & 06 & LBL & & 23 & & & \\
\hline STO I & $330 \mathrm{I}$ & STO & & 33 & $D$ & & 14 & & & \\
\hline 1 & 01 & + & & 61 & - & & 83 & & & \\
\hline STO 6 & 3306 & 2 & & 02 & 2 & & 02 & & & \\
\hline STO 2 & 3302 & 2 & & 02 & 9 & & 09 & & & \\
\hline \multirow[t]{2}{*}{2} & 02 & STO & & 33 & 7 & & 07 & & & \\
\hline & & & & & & & & \multicolumn{3}{|c|}{ Registers } \\
\hline+ & 61 & + & & 61 & 1 & & 01 & \multirow{10}{*}{$\begin{array}{l}\mathrm{R}_{1} \\
\mathrm{R}_{2} \\
\mathrm{R}_{3} \\
\mathrm{R}_{4} \\
\mathrm{R}_{5} \\
\mathrm{R}_{6} \\
\mathrm{R}_{7} \\
\mathrm{R}_{8} \\
\mathrm{R}_{9}\end{array}$} & Used & \multirow{10}{*}{$\alpha_{q}$} \\
\hline sto 3 & 3303 & 3 & & 03 & 8 & & 08 & & Used & \\
\hline RCL 1 & 3401 & EEX & & 43 & STO 5 & 33 & 05 & & Used & \\
\hline CHS & 42 & CHS & & 42 & RTN & & 24 & & Used & \\
\hline$f^{-1}$ & 32 & 4 & & 04 & Gro & & 22 & & $\alpha_{p}$ or & \\
\hline$L N$ & 07 & $\mathrm{RCL} \quad \hat{0}$ & 34 & 06 & $D$ & & 14 & & $\begin{array}{c}\text { P } \\
\text { Used }\end{array}$ & \\
\hline$g$ & 35 & $g x>y$ & 35 & 24 & LBL & & 23 & & Used & \\
\hline$\pi$ & 02 & GTO & & 22 & $E$ & & 15 & & - & \\
\hline$\uparrow$ & 41 & 1 & & 01 & 1 & & 01 & & & \\
\hline+ & 61 & RCL 2 & 34 & 02 & - & & 83 & & & \\
\hline
\end{tabular}


PROGRAM WE-975-?. DETE MMINATION OF ADJUSTED VULNERABILITY

NLIABERS FOR P-TYPE TARGETS

\section{Descriptien}

From the vulnerability number $V N$, of the form $V_{0} P K$, and the weapon yield $\mathrm{W}$, the adjusted vulnerability number $\mathrm{WN}_{\text {adj }}$ is calculated. No approximations are made in the program. Parametrlc studies of $\mathrm{VN}_{\text {adj }}$ as a function of elther $K$ or $W$ are readily effected.

\section{User Instructions}

\begin{tabular}{|c|c|c|c|}
\hline Step & $\begin{array}{l}\text { Instructions / } \\
\text { comments }\end{array}$ & Key & $\begin{array}{c}\text { Output } \\
\text { data/units }\end{array}$ \\
\hline \multirow[t]{2}{*}{1} & Enter program & & \\
\hline & $\begin{array}{l}\text { Vulnerability number is of form } \\
\mathrm{VN}_{0} \mathrm{PK} \text {. }\end{array}$ & & \\
\hline 2 & Enter $\mathrm{VN}_{0}$ & A & $\mathrm{VN}_{0}$ \\
\hline 3 & Enter $\mathbf{K}$ & B & $\mathrm{k} / 10$ \\
\hline 4 & $\begin{array}{l}\text { Enter } W \text { in } M t \text {. } \\
\text { Step } 4 \text { may be repeated for other values of } W \text {. } \\
\text { If it is desired to determine } \mathrm{W}_{\text {adj }} \text { as a function of } \\
\text { key entiy } 11 \text { (see } 1 \text { lsting) may be changed from } \mathrm{R} / \mathrm{s} \text { to } \\
\text { be entered separately, once, in register } 5 \text {. Then ste } \\
\text { calculate } \mathrm{WN} \text { adj as its output and may be repeated for } \\
\text { of } \mathrm{K} \text {. Step } 4 \text { will be deleted. }\end{array}$ & $\begin{array}{l}\text { C } \\
\text { for } \\
\text { RCL5 } \\
3 \text { a } \\
\text { othe }\end{array}$ & $\begin{array}{l}\text { anj } \\
\text { fixed } \mathrm{W}, \\
\text { and } \mathrm{W} \text { must } \\
\text { ove will } \\
\text { values }\end{array}$ \\
\hline PIC & Ining time: less than $10 \mathrm{~s}$ & & \\
\hline
\end{tabular}

\section{Example}

The $\mathrm{VN}$ of a target is $25 \mathrm{P} 6$. What is $\mathrm{VN}_{\text {adj }}$ for a weapon yield of 0.1 Mt? $1 \mathrm{Mt}$ ?

\begin{tabular}{llcrcr}
\hline Step & \multicolumn{1}{c}{$\begin{array}{c}\text { Instructions/ } \\
\text { comments }\end{array}$} & $\begin{array}{c}\text { Input } \\
\text { data/units }\end{array}$ & Key & $\begin{array}{c}\text { Output } \\
\text { data/units }\end{array}$ \\
\hline 1 & Enter program. & 25 & A & -5.00 \\
2 & Enter $\mathrm{VN}_{0^{\circ}}$ & 6 & B & 0.60
\end{tabular}


Example (Cont.)

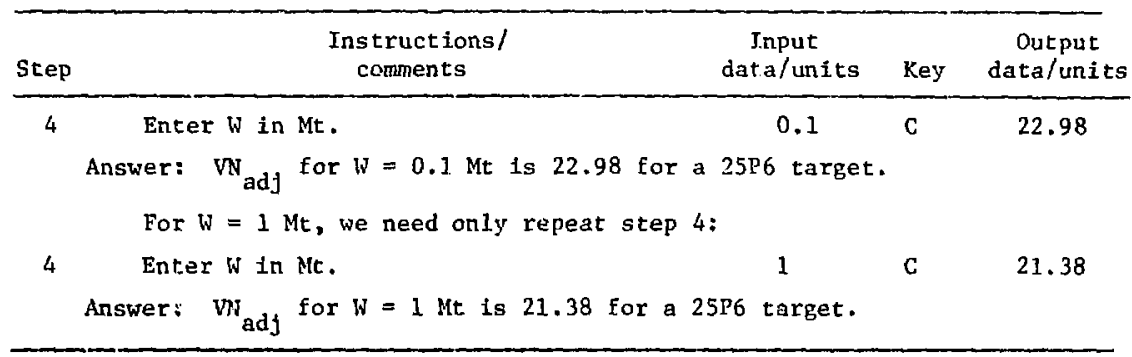

Program WE-975-2 Listing

\begin{tabular}{|c|c|c|c|c|c|c|c|c|c|c|c|c|}
\hline $\begin{array}{l}\text { Key } \\
\text { entry }\end{array}$ & & $\begin{array}{l}\text { ode } \\
\text { own }\end{array}$ & $\begin{array}{c}\text { key } \\
\text { entry }\end{array}$ & $\begin{array}{r}\text { Co } \\
\text { sho }\end{array}$ & $\begin{array}{l}\text { ade } \\
\text { own }\end{array}$ & $\begin{array}{c}\text { Key } \\
\text { entry }\end{array}$ & $\begin{array}{r}\text { Co } \\
\text { sho }\end{array}$ & ode & $\begin{array}{r}\text { Key } \\
\text { entr }\end{array}$ & & $\begin{array}{r}\text { Co } \\
\text { sho }\end{array}$ & $\begin{array}{l}\text { ode } \\
\text { own }\end{array}$ \\
\hline I.BL & & 23 & RCL 4 & 34 & 04 & STO 7 & 33 & 07 & $f$ & & & 31 \\
\hline A & & 11 & - & & 51 & 1 & & 01 & LN & & & 07 \\
\hline STO 3 & 33 & 03 & STO 6 & 33 & 06 & + & & 61 & $\div$ & & & 81 \\
\hline $\mathrm{R} / \mathrm{S}$ & & 84 & RCL 4 & 34 & 04 & + & & 31 & $\mathrm{KCL}$ & 3 & 34 & 03 \\
\hline LBL & & 23 & $\uparrow$ & & 41 & $\sqrt{x}$ & & 09 & + & & & 61 \\
\hline B & & 12 & $\mathrm{x}$ & & 71 & 1 & & 01 & $\mathrm{RTN}$ & & & 24 \\
\hline 1 & & 01 & $\div$ & & 81 & + & & 61 & LBL & & & 23 \\
\hline 0 & & 00 & 4 & & 04 & $\uparrow$ & & 41 & $D$ & & & 14 \\
\hline$\div$ & & 81 & $\mathrm{x}$ & & 71 & + & & 61 & $\mathrm{ICL}$ & 3 & 34 & 03 \\
\hline STO 4 & 33 & 04 & RCL 5 & 34 & 05 & RCL 7 & 34 & 07 & RTN & & & 24 \\
\hline$R / S$ & & 84 & 5 & & 05 & $\div$ & & 81 & \multicolumn{4}{|c|}{ Registers } \\
\hline LRI, & & 23 & 0 & & 00 & 1 & & 01 & \multirow{9}{*}{\multicolumn{2}{|c|}{$\begin{array}{ll}R_{1} & - \\
R_{2} & - \\
R_{3} & V_{0} \\
R_{4} & K / 10 \\
R_{5} & W(M t) \\
R_{6} & 1-K / 10 \\
R_{7} & \text { Used } \\
R_{8} & - \\
R_{9} & \text { Used }\end{array}$}} & & \\
\hline C & & 13 & $x$ & & 71 & + & & $6 !$ & & & & \\
\hline STO 5 & 33 & 05 & 2 & & 02 & RCL 6 & 34 & 06 & & & & \\
\hline RCL 4 & 34 & 04 & $\uparrow$ & & 41 & $\mathrm{x}$ & & 71 & & & & \\
\hline 0 & & 00 & 3 & & 03 & $f$ & & 31 & & & & \\
\hline$g x=y$ & 35 & 23 & $\div$ & & 81 & $\mathrm{LN}$ & & 07 & & & & \\
\hline GTO & & 22 & $\mathbf{g}$ & & 35 & 1 & & 01 & & & & \\
\hline D & & 14 & $y^{x}$ & & 05 & $\cdot$ & & 83 & & & & \\
\hline 1 & & 01 & $x$ & & 71 & 2 & & 02 & & & & \\
\hline
\end{tabular}


PROGRAM WE-975-3. PEAK OVERPRESSURES AND ADJUSTED VULNERABILITY

NUMBERS FOR P-'YYPE TARGETS

\section{Description}

This program is similar to WE-975-2 but has the added feature of computing the peak overpressure $p$ corresponding to $V_{\text {adj }}$ as well as $\mathrm{WN}_{\text {adj }}$ itscif. If the peak overpressure (ordinarily interpreted as that issocjated with a $50 \%$ probability of damage; 1.e., $\mathrm{P}_{0.5}$ of Ref. 1) Is not desired, WE-975-2 is preferable. No approximations are made in the program.

\section{User Inarructions}

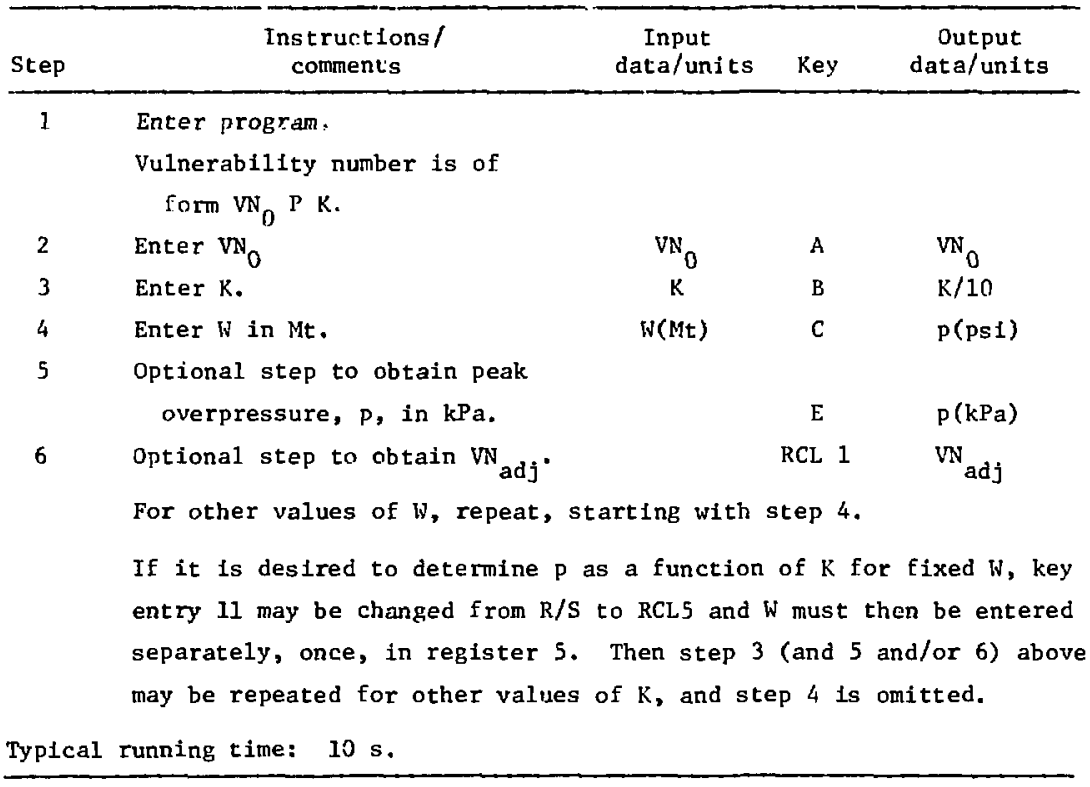


Example

The $\mathrm{VN}$ of a target is 25P6. What are $\mathrm{C}$ and $\mathrm{VN}_{\text {adj }}$ for a weapon yield of $0.1 \mathrm{Mt}$ ? $1 \mathrm{Mt}$ ?

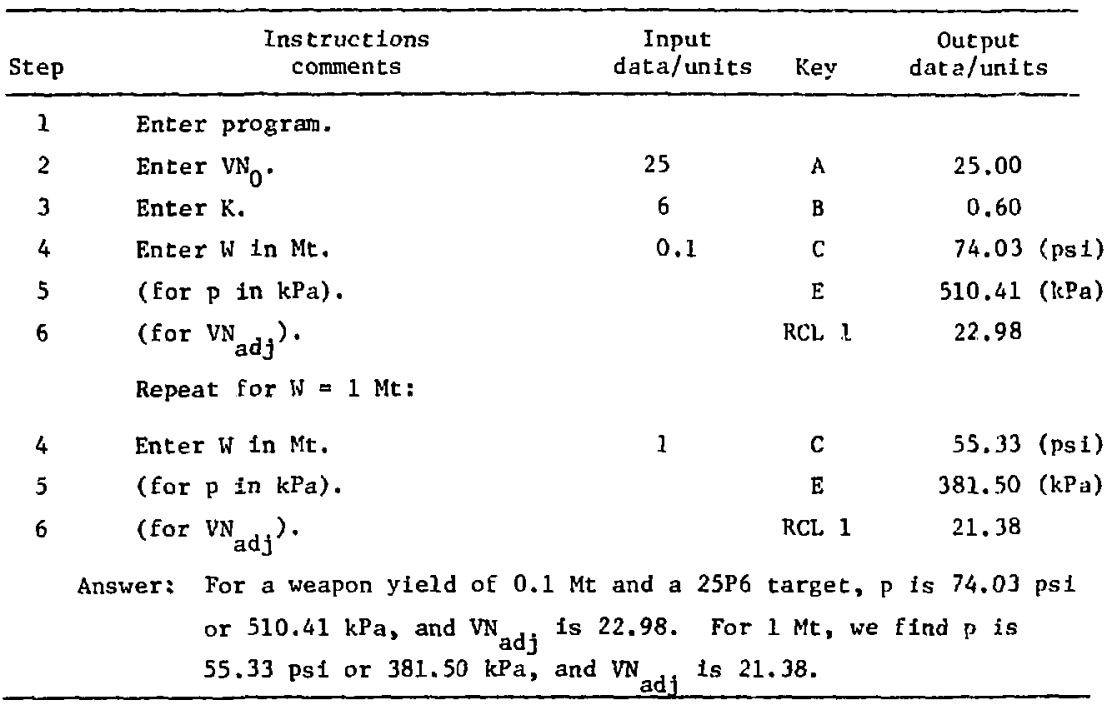


Program WE-975-3 Listing

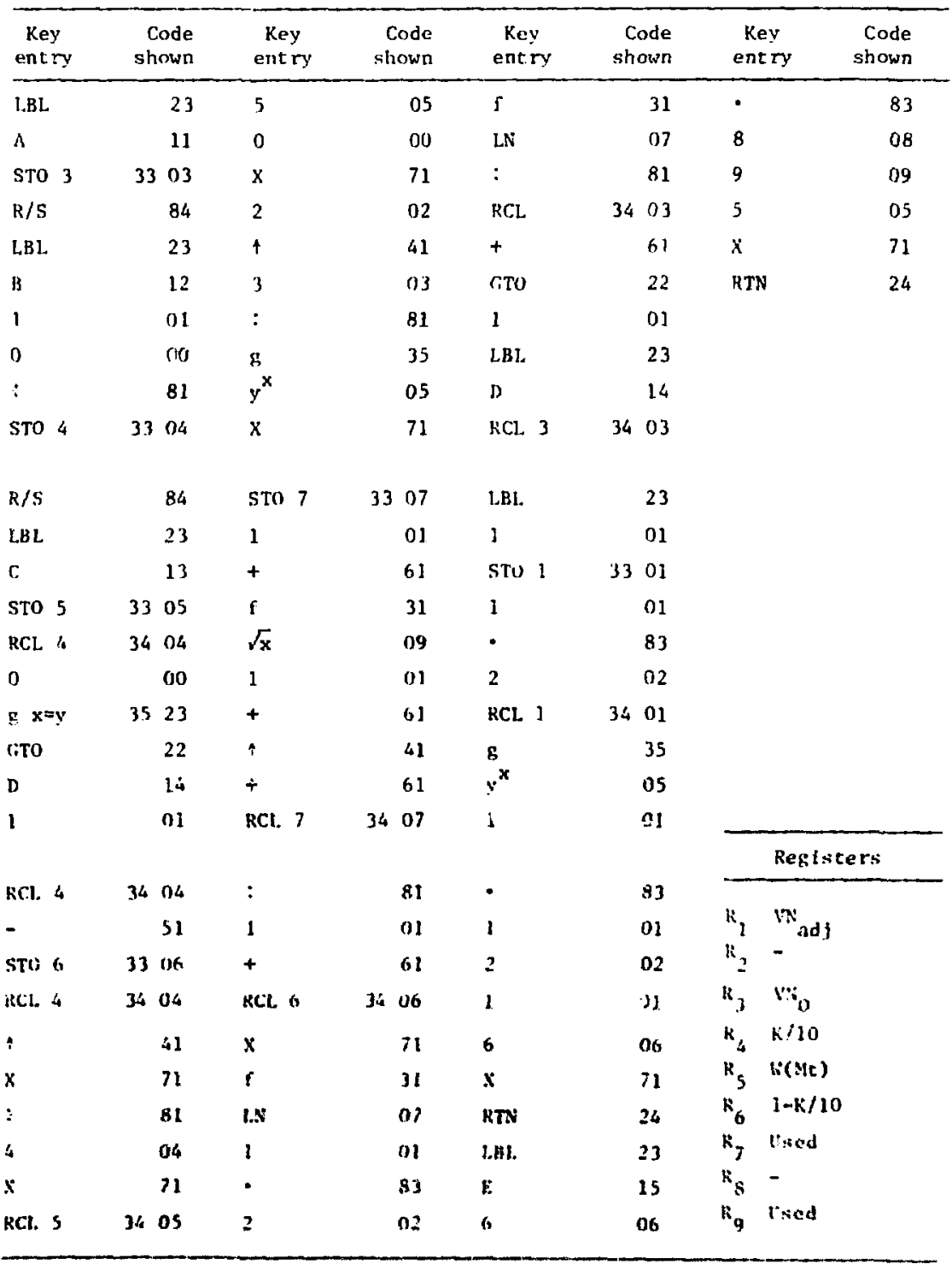


PROGRAY WE-97j-4. $i^{3}$, Wk, AND WR FOR P-TYPF i'UNT TARRETS SURFACE BLEST

\section{Description}

The adjusted vulnerability number $V_{\text {ad }}$, the weapon yield $W(M t)$, and the CEP ( $f t)$ of the delfvery vehfcle are the input parameters for this calculation. Crdinar11y, this program is used after Wt-975-2 without clearing the calculator, in which case $W_{\text {adj }}$ and $W$ are aiready entered for calculation and only the CFP must be entered by the operator. $P_{k}$, the probability of a "k111" at the damage level appropriate to the vulnerability number, 1s determined, as are the scaled weapon radius $W R_{0}$ and the weapon radius WR. Parametric studies based on CEP are particularly Eacile.

Note that the calculation is for P-type point targets and for a surface burst. Error, defined as deviation from the results obtained using Ref. 1, results from an analytic $f t^{2}$ to obtain $W_{0}$ from $\mathrm{VN}_{\text {adj }}$. Typlcally this "error" is less than $5 \%$. No further approximations are incde in obtaining WR and $P_{k}$, so the "error" In $W R$ is the same as that for $W_{0}$ and the "error" in the value of $\mathrm{P}_{k}$ is typlcally no more than \pm 0.02 .

User Instructions

\begin{tabular}{|c|c|c|c|c|}
\hline Step & $\begin{array}{l}\text { Instructions } \\
\text { comments }\end{array}$ & $\begin{array}{l}\text { Input } \\
\text { data/units }\end{array}$ & Key & $\begin{array}{c}\text { Output } \\
\text { data/units }\end{array}$ \\
\hline 1 & $\begin{array}{l}\text { Enter program. } \\
\text { If used after } W E-975-2, W \text { is } \\
\text { in register } 5, \mathrm{VN}_{\text {adj }} \text { is in } \\
\text { the x-regiscer. If not, } \\
\text { enter them in the correct } \\
\text { registers. }\end{array}$ & & A & $\mathrm{WR}_{0}\left(\mathrm{ft} / \mathrm{kt}{ }^{1 / 3}\right)$ \\
\hline 2 & Enter CEP. & $\operatorname{CEP}(\mathrm{f} t)$ & B & $p_{k}$ \\
\hline 3 & $\begin{array}{l}\text { Optional step to obtain WR } \\
\text { if desired. }\end{array}$ & & RCL 4 & $\mathrm{WR}(\mathrm{ft})$ \\
\hline & Step 2 may be repeated for other & CEP's: & & \\
\hline 2 & Enter CEP. & & $\mathrm{B}$ & $\mathrm{P}_{\mathrm{k}}$ \\
\hline 3 & $\begin{array}{l}\text { Optional step to obtain WR } \\
\text { if desired. }\end{array}$ & & RCL 4 & WR $(f t)$ \\
\hline
\end{tabular}




\section{Example}

What are $P_{k}$, WR ${ }_{0}$, and WR for the first examnle of WE-975-2 (a 25P6 target with $W$ of $0.1 \mathrm{Mt}$ ) for a 1000-ft CEP?

For these conditions, we found in WE-975-2 that VN $\mathrm{Ndj}_{\mathrm{j}}$ was 22.98. Ordinarily, however, WE-975-4 is used as a continuation of WE-975-2, so that program is run first.

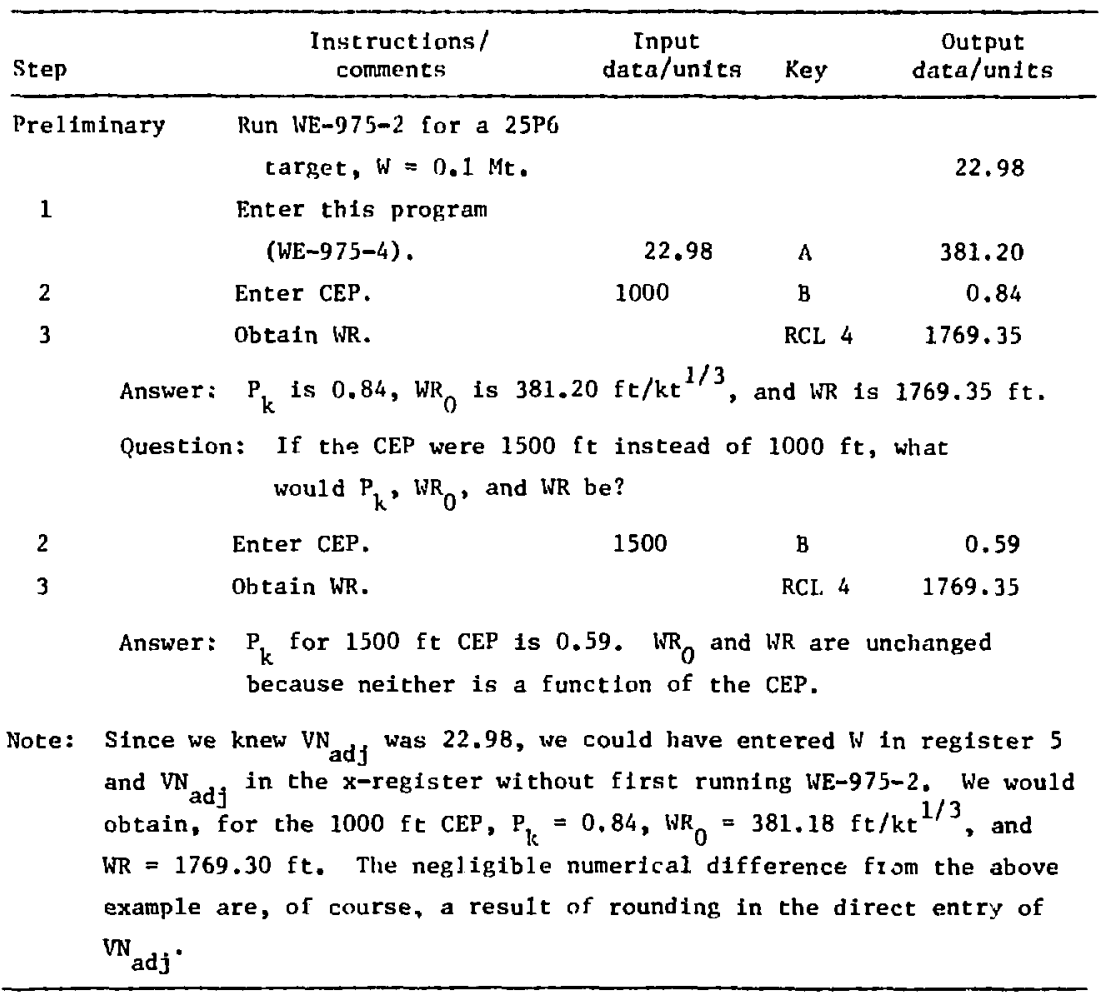


Program WE-975-4 Listing

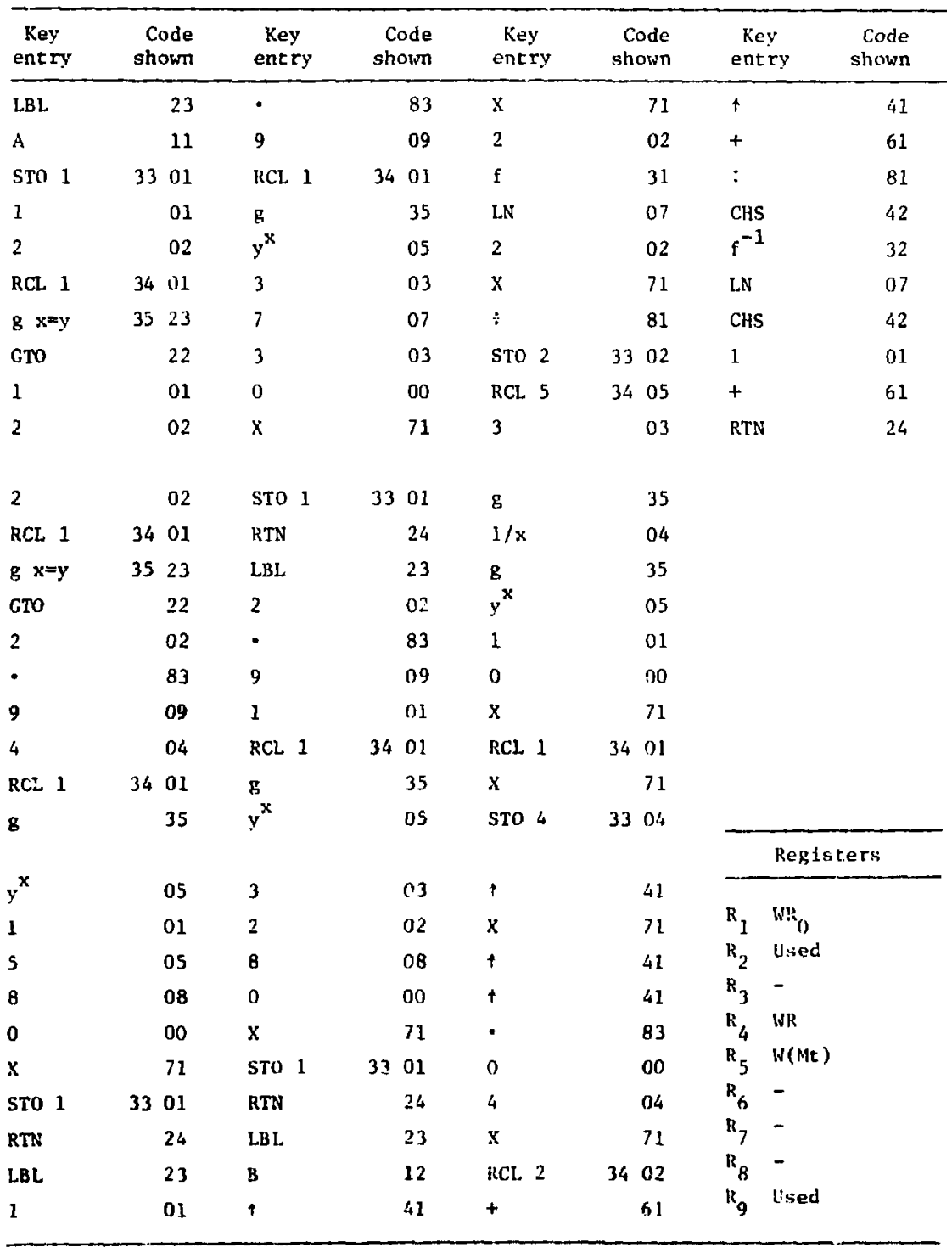


PROGRAM WE-975-5. $P_{k}$, WR ${ }_{0}$, AND WR FOR P-TYPE POINT TARGETS OPTIMUM HEIGHT OF BLKST

\section{Description}

The adjusted vulnerability number $V{ }_{\text {adj }}$, the weapon yield $W(M t)$, and the CEP ( $f t$ ) of the delivery vehicle are the input parameters for this calculation, ordinarily, this program is used after WE-975-2 without clearing the calculator, In which case $V_{\text {adj }}$ and $W$ are clready entered for calculation and only the CEP must be entered by the operator. $P_{k}$, the probability of a "kill" at the damage level approprlate to the vulnerability number, is determined, as are the scaled weapon radius $W_{0}$ and the weapon radius $W R$.

Note that the calculation is for P-type point targets and for optimum height of burst. Optimum height of burst for this program is defined by an empirtcal fit, ${ }^{2}$ based on Table I-16 of Ref. 1, that maximizes the scaled weapon radius as a function of scaled height of burst. Error, defined as deviation from the results obtained using Ref. 1, is typically less than $5 \%$. No further approximations are made in obtaining $W R$ and $P_{k}$, so the "error" for $W R$ is the same as that for $W_{0}$ and the "error" in the value of $p_{k}$ is typically no more than \pm 0.02 .

\section{User Instructions}

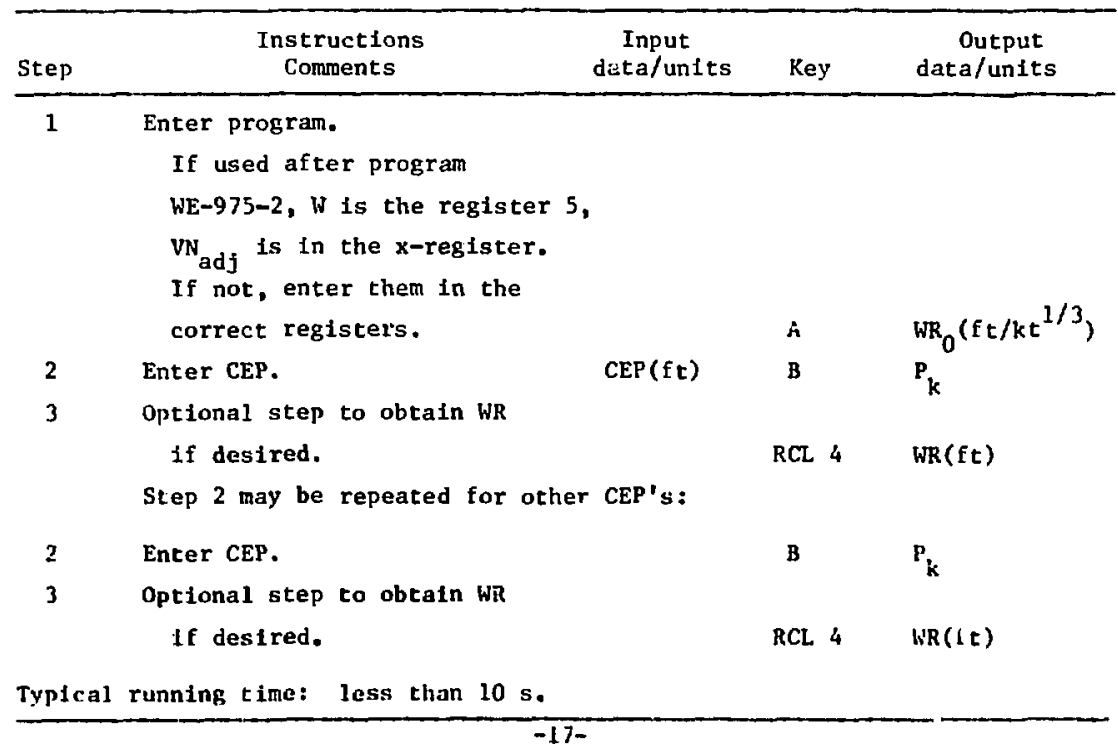


Example

What are $P_{k}$, $W R_{0}$, and $W R$ for the first example of WE-975-2 (a 25P6 target with $W$ of 0.1 Mt) for a 1000-ft CEP?

For these conditions, we found In WE-975-2 that $V N_{\text {adj }}$ was 22.98. Ordinarily, however, WE-975-5 is used as a continuation of WE-975-2, so that program is run first.

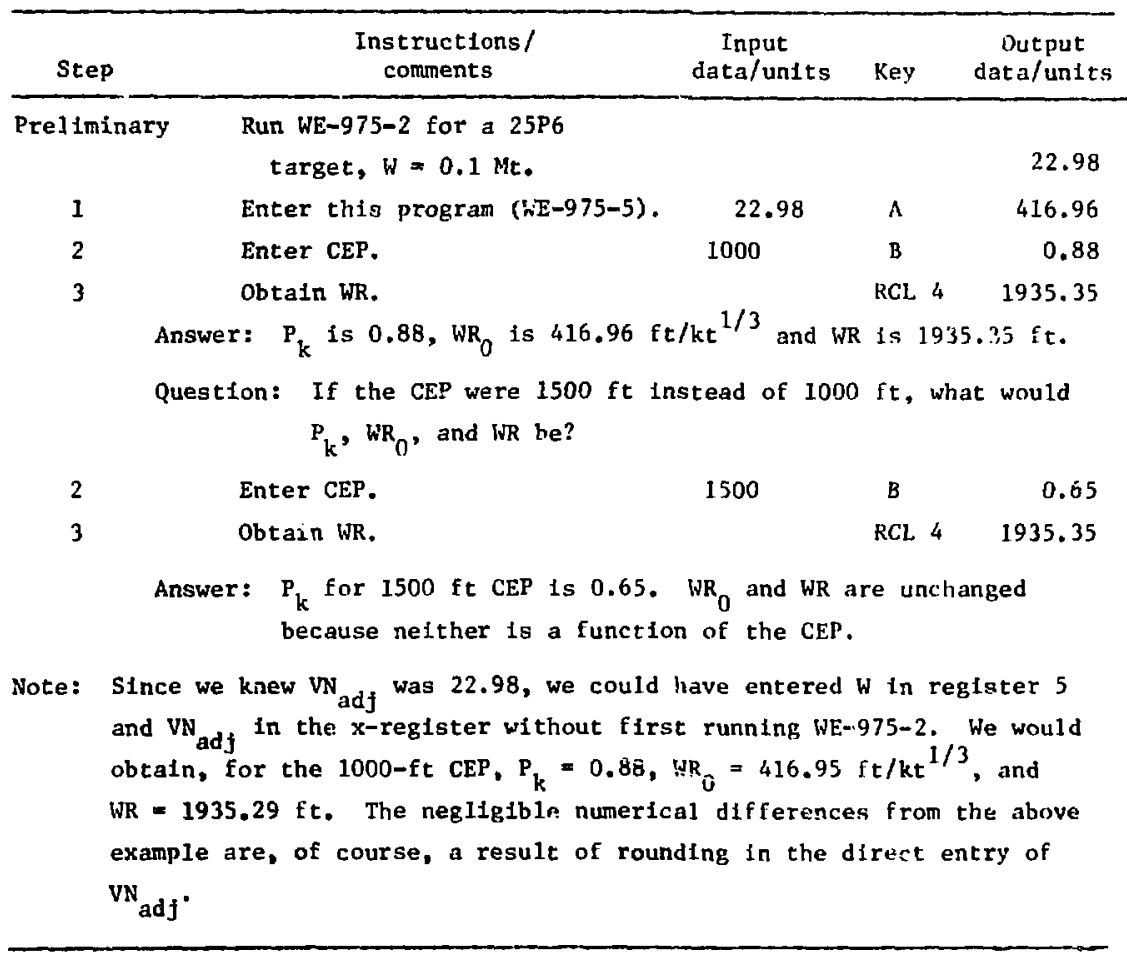


Program WE-975-5 Listing

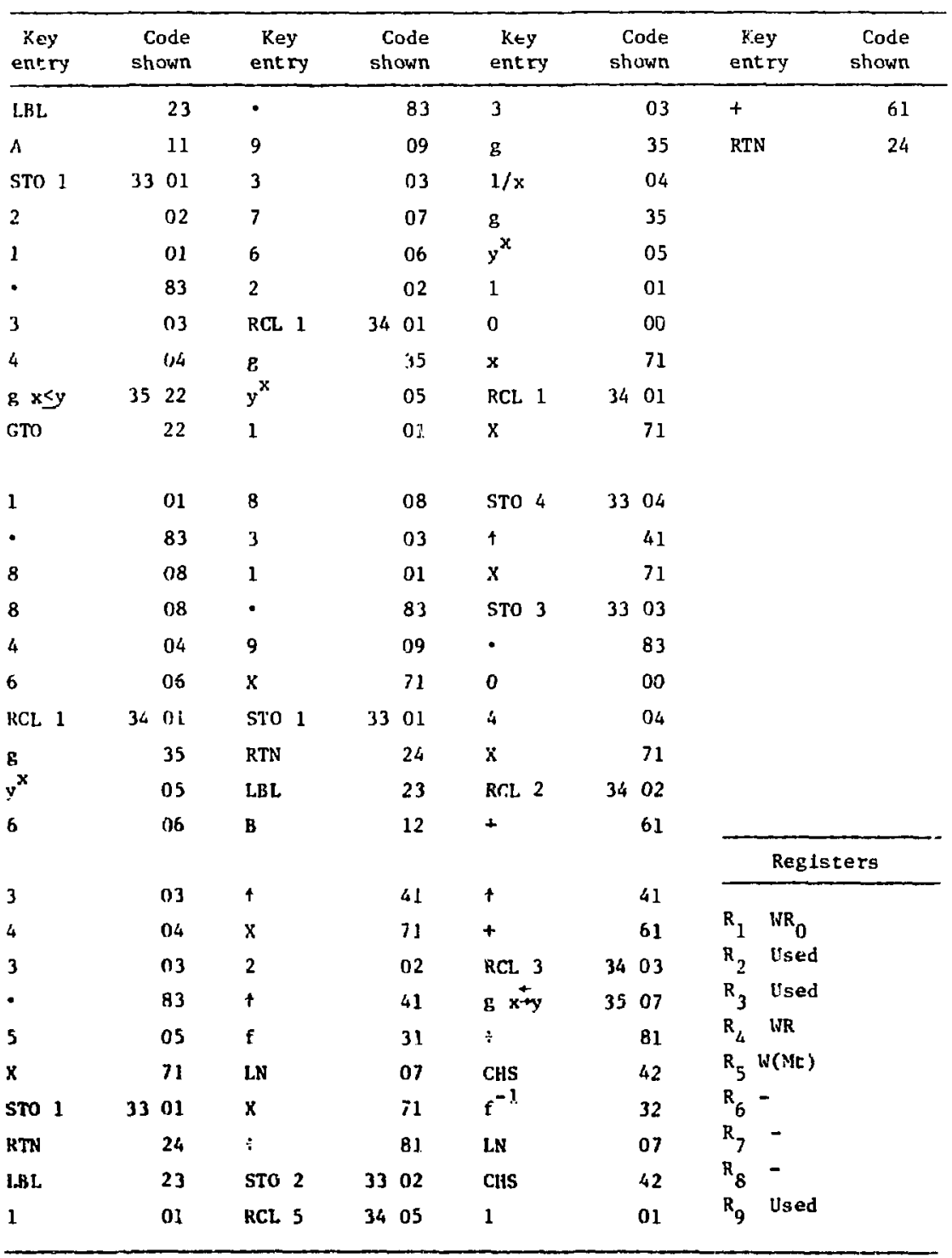


PROGRAM WE-975-6, DETERMTNATION OF ADJUSTED VITNERABILI'TY

NUNLERS FOK Q-TYPE TARGETS

\section{Descrintion}

From the vulnerabiltty number $V N$, of the form $W_{0} \& k$, and the weapon yleld $W$, the adjusted vulnerability number $W_{\text {adj }}$ is calculated. An iteration made in the program could result in an "error" of no more than 1 tn the second decimal place of $\mathrm{VN}_{\text {adj }}$. Perametrle studies of $\mathrm{VN}_{\text {adj }}$ as a function if elther $K$ or $W$ are readlly effected.

\section{User Instructions}

\begin{tabular}{|c|c|c|}
\hline Step & $\begin{array}{c}\text { Instructions } \\
\text { comments }\end{array}$ & $\begin{array}{c}\text { Output } \\
\text { data/units }\end{array}$ \\
\hline 1 & $\begin{array}{l}\text { Enter program. } \\
\text { Vulnerability number is } \\
\text { of form } \mathrm{WN}_{0} \mathrm{Q} \mathrm{K} \text {. }\end{array}$ & \\
\hline 2 & Enter $\mathrm{VN}_{0}$ & $\mathrm{~N}_{0}$ \\
\hline 3 & Enter $\mathbf{K}$. & $\mathrm{K} / \mathrm{IO}$ \\
\hline 4 & $\begin{array}{l}\text { Enter } W \text { in } M t \text {. } \\
\text { Step } 4 \text { may be repeated for other values of } W \text {. } \\
\text { If it is desired to determine } W_{\text {adj }} \text { as a funct } \\
\text { key entry } 11 \text { (see } 1 \text { isting) may be changed from } \\
\text { must then be e' }-1 \text { ed separately, once, in regi } \\
\text { above will calculace } \mathrm{VN}_{\text {adj }} \text { as its output and m } \\
\text { other values of } \mathrm{K} \text {. Step } 4 \text { will be deleted. }\end{array}$ & $\begin{array}{l}C \\
\text { of } K \text { for fixed } W \text {, } \\
\text { S to } \operatorname{RCL} 5 \text {, and } W \\
\text { b. Then, step } 3 \\
\text { be repeated for }\end{array}$ \\
\hline
\end{tabular}

Typical running time: $15 \mathrm{~s}$.

Exanple

The VN of a target is 25Q6. What is VN adj for a weapon yield of $0.1 \mathrm{Mt}$ ? $1 \mathrm{Mt}$ ?

\begin{tabular}{llrrr}
\hline \multicolumn{1}{c}{$\begin{array}{c}\text { Instructions } \\
\text { comments }\end{array}$} & $\begin{array}{c}\text { Input } \\
\text { data/units }\end{array}$ & Key & $\begin{array}{c}\text { Output } \\
\text { data/units }\end{array}$ \\
\hline 1 & Enter program. & & & \\
2 & Enter NN $_{0^{*}}$ & 25 & A & 25.00 \\
3 & Enter K. & 6 & B & 0.60
\end{tabular}


Example (Cont.)

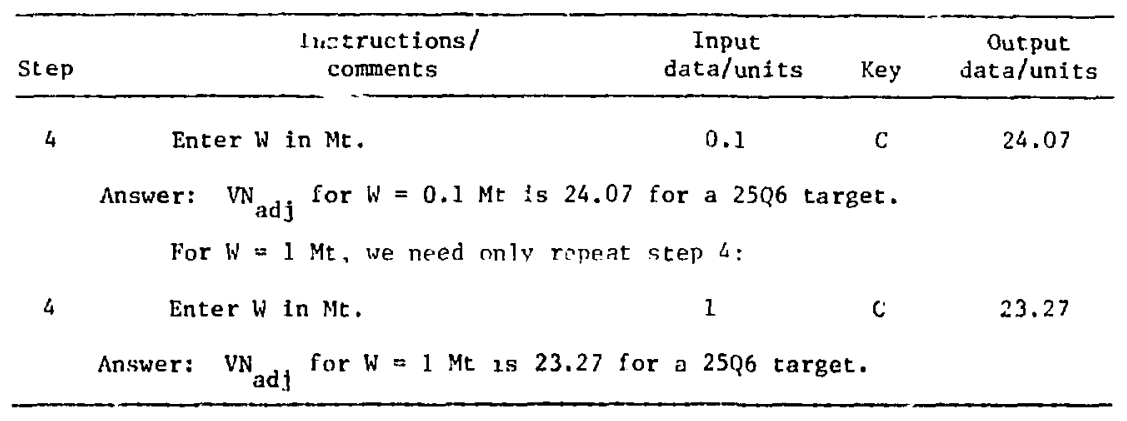

\section{Program WE-975-6 Listing}

\begin{tabular}{|c|c|c|c|c|c|c|c|c|c|c|}
\hline $\begin{array}{c}\text { Key } \\
\text { entry }\end{array}$ & $\begin{array}{r}\text { Code } \\
\text { shown }\end{array}$ & $\begin{array}{c}\text { Key } \\
\text { entry }\end{array}$ & & $\begin{array}{l}\text { ode } \\
\text { own }\end{array}$ & $\begin{array}{c}\text { Key } \\
\text { entry }\end{array}$ & $\begin{array}{r}\text { Co } \\
\text { sho }\end{array}$ & $\begin{array}{l}\text { ode } \\
\text { own }\end{array}$ & $\begin{array}{l}\text { Key } \\
\text { entry }\end{array}$ & & $\begin{array}{r}\text { Code } \\
\text { shown }\end{array}$ \\
\hline LBL & 23 & $\mathrm{~g}$ & & 35 & 1 & & 01 & $\mathbf{f}$ & & 31 \\
\hline$\Lambda$ & 11 & $1 / x$ & & 04 & + & & $E 1$ & LN & & 07 \\
\hline STO 3 & 3303 & g & & 35 & RCL 4 & 34 & 04 & 1 & & 01 \\
\hline $\mathrm{R} / \mathrm{S}$ & 84 & $y^{x}$ & & 05 & - & & 51 & • & & 83 \\
\hline LBL & 23 & KCL 4 & 34 & 04 & STC 6 & 35 & 06 & 4 & & 04 \\
\hline $\mathrm{B}$ & 12 & $\mathrm{x}$ & & 71 & RCL 1 & 34 & 01 & 4 & & 04 \\
\hline 1 & 01 & STO 2 & 33 & 02 & - & & 51 & $\mathrm{f}$ & & 31 \\
\hline 0 & 00 & 1 & & 01 & $\mathrm{~B}$ & & 35 & LN & & 07 \\
\hline$\div$ & 81 & STO 6 & 33 & 06 & $A B S$ & & 06 & $\div$ & & 81 \\
\hline STO 4 & 3304 & LBL & & 23 & EEX & & 43 & RLL & 3 & 3403 \\
\hline$R / S$ & 84 & 1 & & 01 & CHS & & 42 & + & & 61 \\
\hline LBL & 23 & RCL 6 & 34 & 06 & 3 & & 03 & RTN & & 24 \\
\hline $\mathbf{C}$ & 13 & STO 1 & 33 & 01 & $g \quad x>y$ & 35 & 24 & \multicolumn{3}{|c|}{ Registers } \\
\hline STO 5 & $\begin{array}{r}3305 \\
83\end{array}$ & $\begin{array}{l}3 \\
\mathrm{~g}\end{array}$ & & $\begin{array}{l}03 \\
35\end{array}$ & $\begin{array}{l}\text { GTO } \\
\text { D }\end{array}$ & & $\begin{array}{l}22 \\
14\end{array}$ & \multirow{6}{*}{$\begin{array}{l}\mathrm{R}_{1} \\
\mathrm{R}_{2} \\
\mathrm{R}_{3} \\
\mathrm{R}_{4} \\
\mathrm{R}_{5} \\
\mathrm{R}_{6} \\
\mathrm{R}_{7} \\
\mathrm{R}_{8} \\
\mathrm{R}_{9}\end{array}$} & Used & \\
\hline 0 & 00 & $1 / x$ & & 04 & GTO & & 22 & & Used & \\
\hline 2 & 02 & $\mathrm{~g}$ & & 35 & 1 & & 01 & & $\mathrm{VN}_{0}$ & \\
\hline$g \overrightarrow{x+y}$ & $\begin{array}{ll}35 & 07\end{array}$ & $y^{x}$ & & 05 & LBL & & 23 & & $\mathrm{~K} / 10$ & \\
\hline$\div$ & 81 & RCL 2 & 34 & 02 & D & & 14 & & $W(M c)$ & \\
\hline 3 & 03 & $x$ & & 71 & $\mathrm{RCL} 6$ & 34 & 06 & & $\begin{array}{l}\text { Used } \\
- \\
- \\
\text { Used }\end{array}$ & \\
\hline
\end{tabular}




\section{Description}

This program is similar to $\mathrm{WE}-975-6$ but has the added feature of computing the peak dynamic pressure corresponding to $\mathrm{VN}_{\text {adj }}$ as well as VN adj itself. If the peak dynamic pressure (ordinarily interpreced as that associated with a $50 \%$;robability of damage; i.e., $q_{0.5}$ of Ref. 1) is not destred, WE-975-6 is preferable. An interation made in the program could result in an "error" of no more than 1 in the second decimal plice of VN adj. No other approximations are made in the program.

\section{User Instructions}

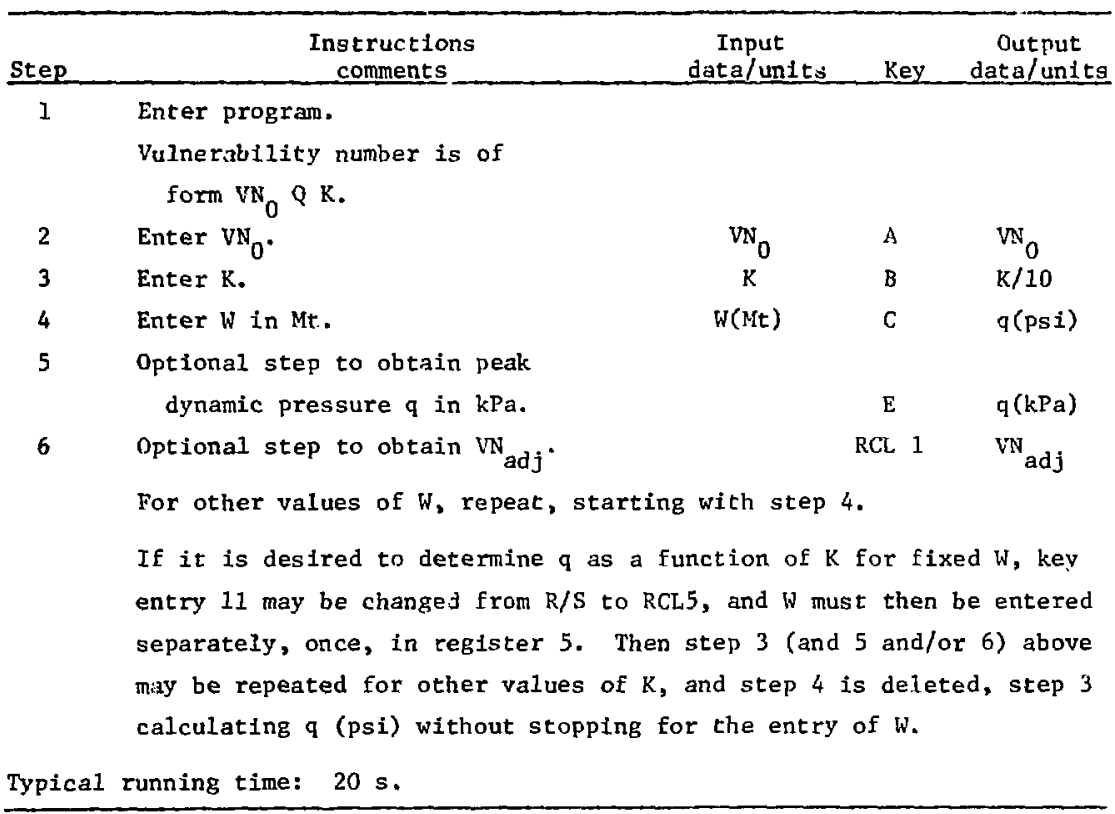


Example

The $\mathrm{VN}$ of a target is $25 \mathrm{Q} 6$. What are $\eta$ and $\mathrm{VN}_{\text {adj }}$ for a weapon $y$ ield of $0.1 \mathrm{Mt}$ ? $1 \mathrm{Mt}$ ?

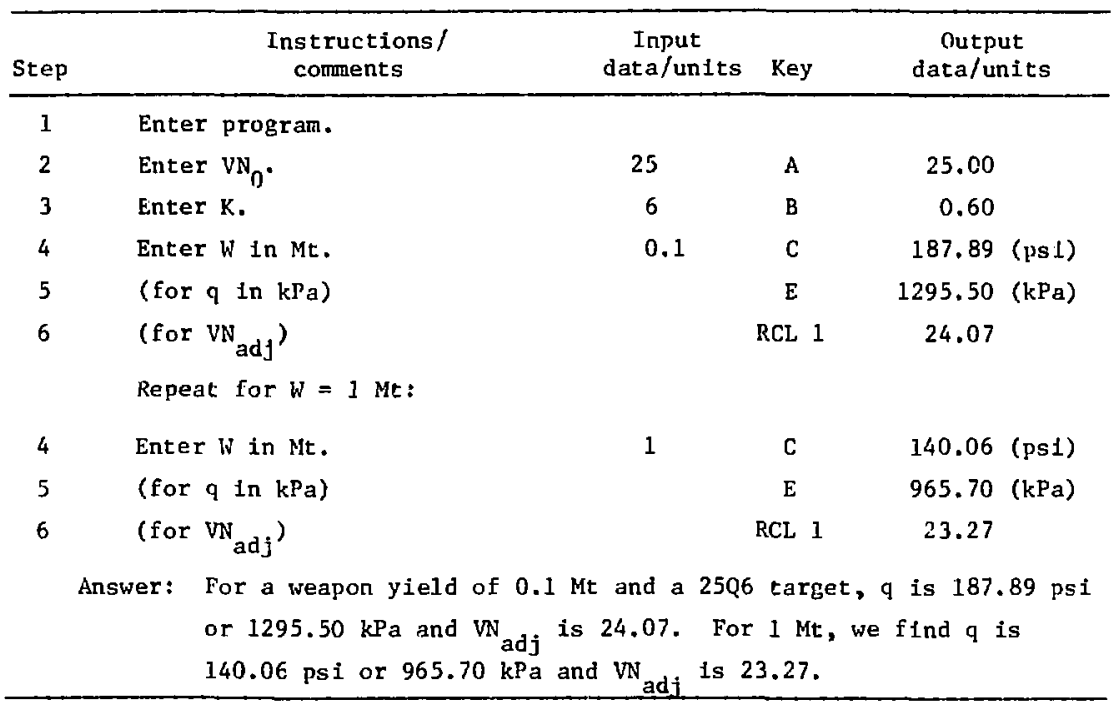


Program WE-975-7 Listing

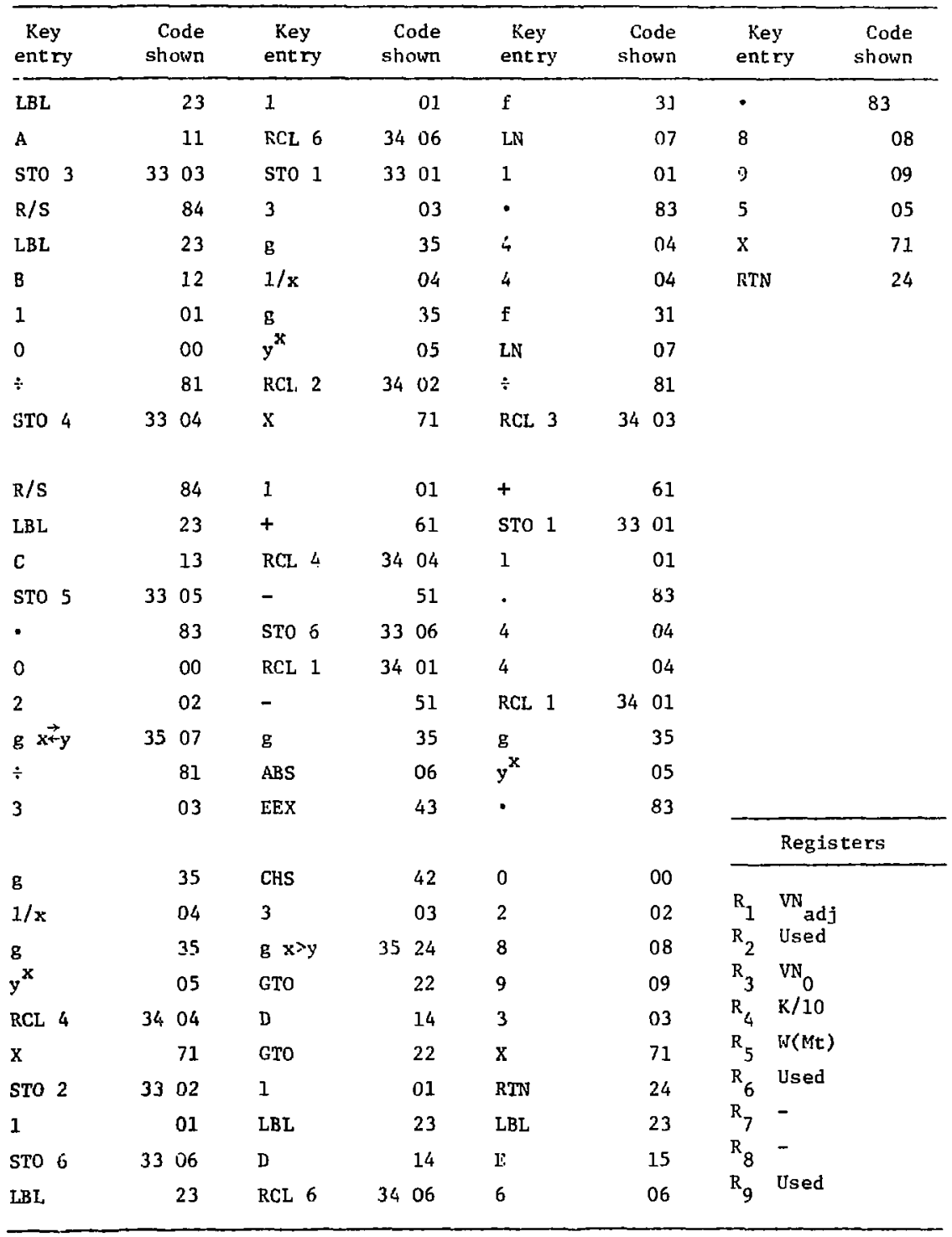


PROGRAM WE-975-8. $\mathrm{P}_{\mathrm{k}}$, WR ${ }_{0}$, AND WR FOR Q-TYPE POINT TARGETS SURFACE BURST

\section{Description}

The adjusted vulnerability number $\mathrm{VN}_{\text {adj }}$, the weapon yleld $\mathrm{W}(\mathrm{Mt})$, and the CEP ( $f t$ ) of the delivery vehicle are the input parameters for this calculation. Ordinarily, this program is used after WE-975-6 without clearing the calculator, in which case $\mathrm{w}_{\text {adj }}$ and $W$ are already entered for calcilation and only the CEP must be entered by the operator. $P_{k}$, the probabllity of a "ki11" at the damage level appropriate to the vulnerability number, is determined, as are the scaled weapon radius $W R_{0}$ and the weapon radius WR. Parametrlc studies based on CEP are particularly facile.

Note that the calculations is for Q-type point targets and for a surface burst. Error, defined as deviation from the results obtained using Ref. 1 , results from an analytic fit ${ }^{2}$ to obtaln $W_{0}$ from $V_{\text {adj }}$. Typically, this "error" is less than 5\%. No further approximations are made in obtaining WR and $P_{k}$, so the "error" in WR is the same as that for $W R_{0}$ and the "error" in the value of $P_{k}$ is typically no more than \pm 0.02 .

\section{User Instructions}

\begin{tabular}{|c|c|c|c|c|}
\hline Step & $\begin{array}{l}\text { Inst ructions } \\
\text { comments }\end{array}$ & $\begin{array}{l}\text { Input } \\
\text { data/units }\end{array}$ & Key & $\begin{array}{c}\text { Output } \\
\text { data/units }\end{array}$ \\
\hline 1 & $\begin{array}{l}\text { Enter program. } \\
\text { If used after WE-975-6, } \\
W \text { is in register } 5 \text {, } \\
\text { VN }{ }_{\text {adj }} \text { is in the } x-\text { register, } \\
\text { If not, enter them in the } \\
\text { correct registers. }\end{array}$ & & A & $\mathrm{WR}_{0}\left(\mathrm{ft} / \mathrm{kt}^{1 / 3}\right)$ \\
\hline 2 & Enter CEP & $\operatorname{CEP}(f t)$ & B & $P_{k}$ \\
\hline 3 & $\begin{array}{l}\text { optional step to obtain WR } \\
\text { if desired. }\end{array}$ & & RCL 4 & $W R(f t)$ \\
\hline & Step 2 nay ie repeated for other & CEP's: & & \\
\hline 2 & Fnter CEP. & & B & $\mathrm{P}_{\mathrm{k}}$ \\
\hline 3 & $\begin{array}{l}\text { Optional scep to obtain WR } \\
\text { if desired. }\end{array}$ & & RCL 4 & WR (ft) \\
\hline Typical & running time: 1 ess than $10 \mathrm{~s}$. & & & \\
\hline
\end{tabular}




\section{Example}

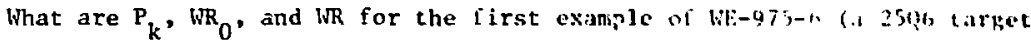
with $\mathrm{W}$ of $0.2 \mathrm{Mt}$ ) fot a 1000-ft CEP?

For these conditions, we found in WF-975-6 that $v$ adj $_{\text {was }} 34,07$. Ordlnar11y, however, WE-975-8 is used as a continuation of Wt:-975-6, so that program is run first.

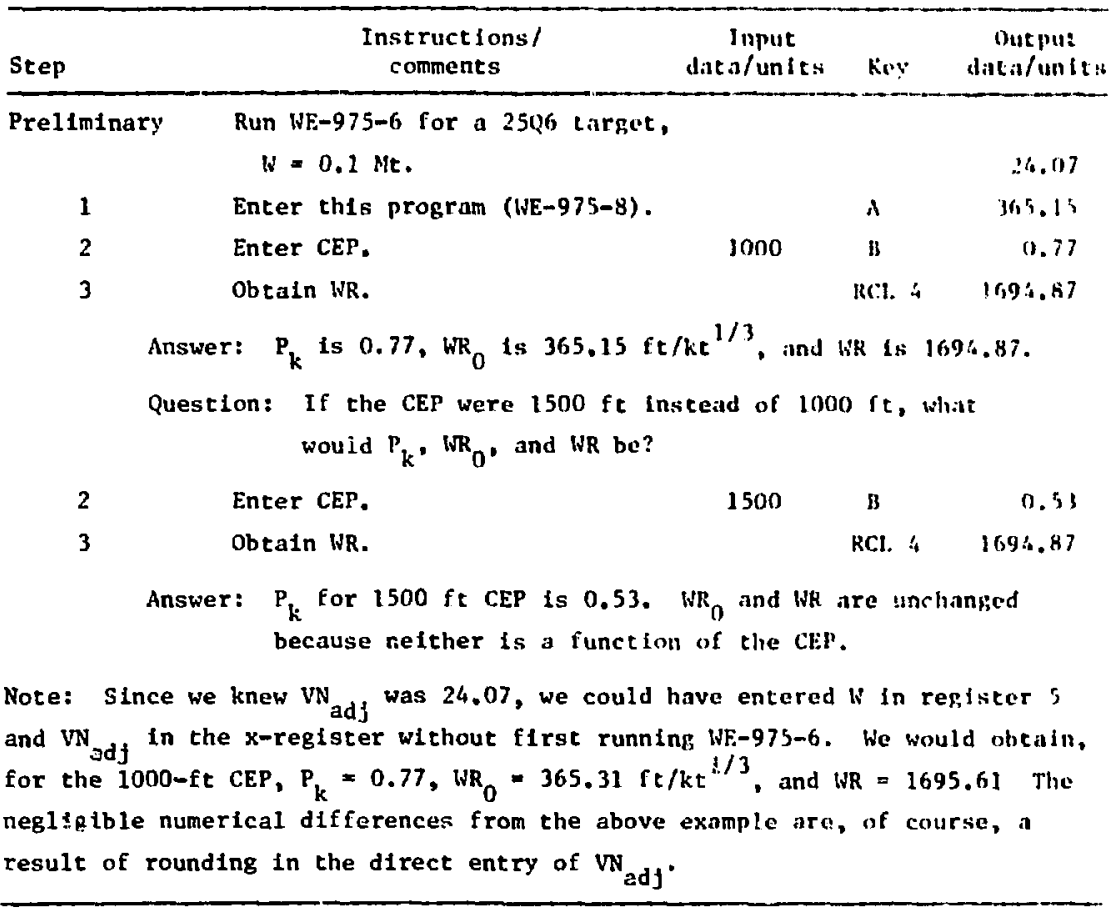




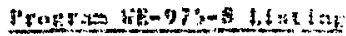

\begin{tabular}{|c|c|c|c|c|c|c|c|c|c|}
\hline $\begin{array}{l}\text { Hoy } \\
\text { me }\end{array}$ & & ade & $\begin{array}{l}\text { Key } \\
\text { catery }\end{array}$ & $\begin{array}{l}\text { ris } \\
\text { : ther }\end{array}$ & oth & $\begin{array}{c}\text { Boy } \\
\text { chery }\end{array}$ & 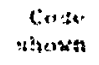 & $\begin{array}{l}\text { fery } \\
\text { ontert }\end{array}$ & $\begin{array}{l}\text { Codto } \\
\text { sturs:s }\end{array}$ \\
\hline I.MI. & & 23 & 0 & & $0 y$ & 0 & as & & \\
\hline$\lambda$ & & 11 & tuct. 1 & ]: & $0 !$ & $x$ & 31 & & \\
\hline stu 1 & II & mi & - & & a) & exct. 1 & I: 01 & & \\
\hline 1 & & $n$ & 3 & & $\eta$ & $x$ & $i 1$ & & \\
\hline 5 & & os & 11 & & 00 & sto i & 3) 0.8 & & \\
\hline met: i & 34 & 01 & $y$ & & 09 & $\cdot$ & $\therefore 1$ & & \\
\hline$x=y$ & 3' & 22 & $x$ & & 71 & $x$ & 71 & & \\
\hline$(. T)$ & & 22 & $1^{-1}$ & & 32 & • & is & & \\
\hline 1 & & 01 & $1 x$ & & 07 & ' & $\therefore 1$ & & \\
\hline 1 & & 03 & $:$ & & BI & - & 53 & & \\
\hline I & & (1) & sta 1 & 37 & al & 0 & an & & \\
\hline s & & os & $\operatorname{stn}$ & & 21 & 9 & 09 & & \\
\hline 0 & & on & I.t. & & 23 & $x$ & 71 & & \\
\hline RcI. 1 & 34 & 01 & il & & 12 & HCl. 2 & 3402 & & \\
\hline - & & 83 & " & & 21 & + & 61 & & \\
\hline 0 & & 00 & $x$ & & 71 & 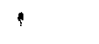 & $\$ 1$ & & \\
\hline 8 & & 08 & 2 & & 02 & + & 61 & & \\
\hline 9 & & 09 & $r$ & & 31. & $:$ & 81 & & \\
\hline 9 & & U9 & 1.9 & & 07 & cus & $\$ 2$ & & \\
\hline$x$ & & 71 & 2 & & 02 & $r^{-1}$ & 32 & & \\
\hline & & & & & & & & \multicolumn{2}{|c|}{ Risglsters } \\
\hline$f^{-1}$ & & 32 & $x$ & & 71 & LS & 07 & \multirow{10}{*}{\multicolumn{2}{|c|}{$\begin{array}{ll}k_{1} & w k_{0} \\
R_{2} & \text { vsed } \\
R_{3} & - \\
R_{4} & W R \\
R_{5} & W(M t) \\
R_{6} & - \\
R_{7} & - \\
R_{8} & - \\
R_{9} & W N_{a d j}\end{array}$}} \\
\hline$L N$ & & 07 & $:$ & & 81 & chs & 42 & & \\
\hline : & & 81 & STO 2 & 33 & 02 & 1 & 01 & & \\
\hline sto 1 & 33 & 01 & RCL. 5 & 34 & 05 & + & 61 & & \\
\hline RTN & & 24 & 3 & & 03 & RTN & 24 & & \\
\hline LBL & & 23 & E & & 35 & & & & \\
\hline 1 & & 01 & $1 / x$ & & 04 & & & & \\
\hline 4 & & 04 & 8 & & 35 & & & & \\
\hline 1 & & 01 & $y^{x}$ & & 05 & & & & \\
\hline 0 & & 00 & 1 & & 01 & & & & \\
\hline
\end{tabular}


PROGRAM WE-975-9. OVERPRESSURE OR DYNAMIC PRESSURE. FROM THE ADJUSTED VULNERABILITY NUMBER.

\section{Description}

This program determines the peak overpressure or peak dynamic pressure from $V N_{\text {adj }}$ for efther P-type or Q type targets. The pressures obtained are ordinarily interpreted as those assoclated with $50 \%$ probability of damage $P_{0.5}$ or $q_{0.5}$ of Ref. 1. Results may be obtalned in either psi or kPa or both. This program does not in any way equate the two types of vulnerability numbers or pressures. Because the individual calculations are short, both the P-type and the Q-type calculations are contajned in one program but they are not used together. Calculat fons w11l be accurate to at least four significant figures.

\section{User Instructions}

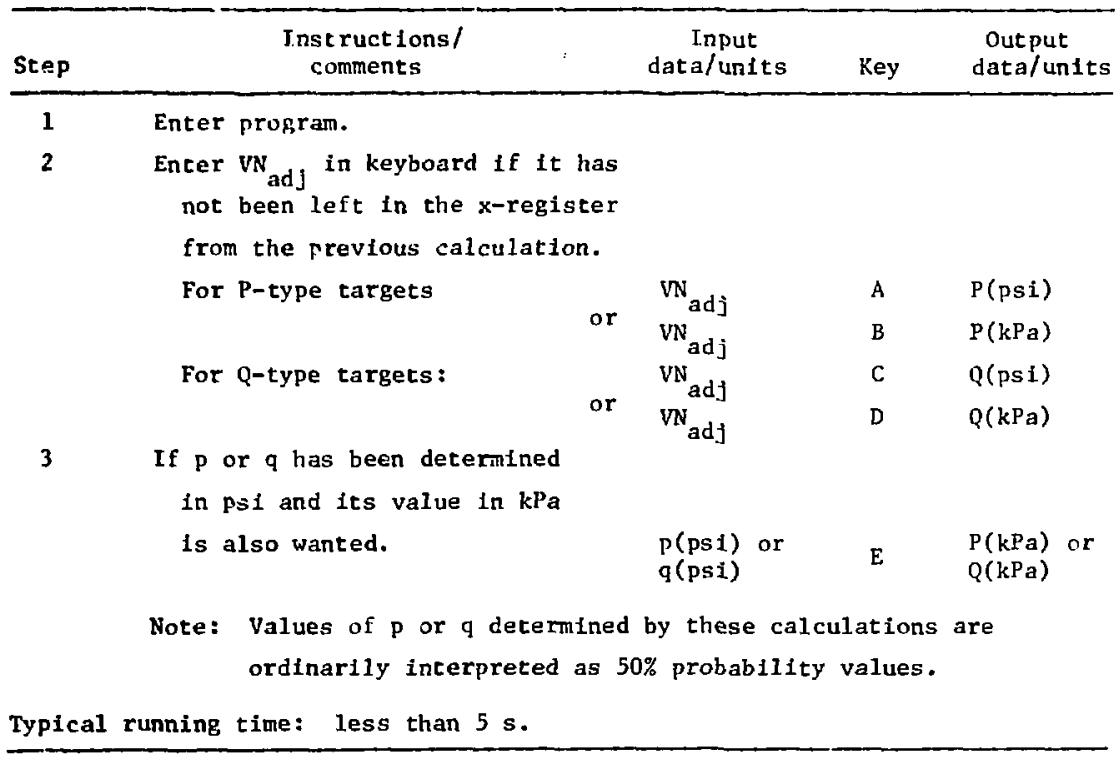




\section{Eximple}

1. For a P-type target, $\mathrm{WN}_{\text {adj }}$ hás been determined to be 22.98. To what peak overpressure does thls correspond?

2. For a Q-type target, $V x_{i d j}$ has heen determined to be 24.07 . To what peak dynamic pressure does this correspond?

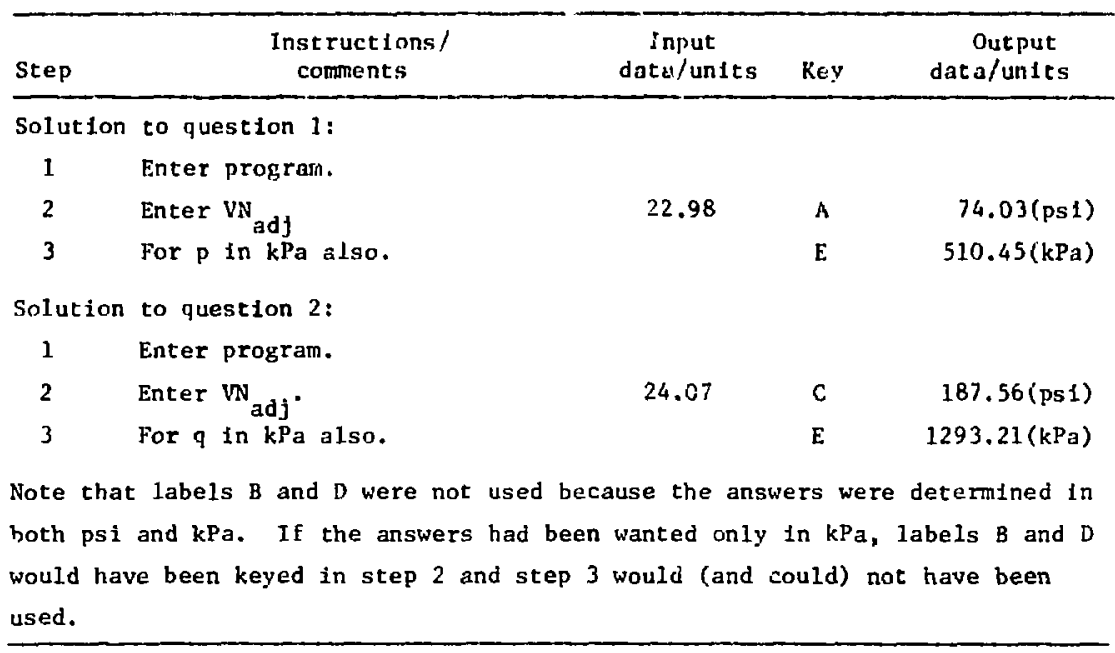


Program WE-975-9 l.1stiur

\begin{tabular}{|c|c|c|c|c|c|c|c|}
\hline $\begin{array}{c}\text { Key } \\
\text { entry }\end{array}$ & $\begin{array}{r}\text { Code } \\
\text { shown }\end{array}$ & $\begin{array}{l}\text { Key } \\
\text { encry }\end{array}$ & $\begin{array}{l}\text { Code } \\
\text { shownt }\end{array}$ & $\begin{array}{l}\text { key } \\
\text { encry }\end{array}$ & $\begin{array}{r}\text { Code } \\
\text { shown }\end{array}$ & $\begin{array}{c}\text { key } \\
\text { entry }\end{array}$ & $\begin{array}{l}\text { Code } \\
\text { thown }\end{array}$ \\
\hline L.BL & 23 & 6 & 06 & 8 & 08 & 9 & 09 \\
\hline $\boldsymbol{A}$ & 11 & - & 83 & 9 & 09 & 5 & 05 \\
\hline ST0 1 & 3301 & 8 & 08 & 3 & 03 & $x$ & 71 \\
\hline 1 & 01 & 9 & 09 & $x$ & 71 & RTN & 24 \\
\hline$\cdot$ & 83 & 5 & 05 & RTN & 24 & & \\
\hline 2 & 02 & $x$ & 71 & LBL & 23 & & \\
\hline RCL 1 & 3401 & RTN & 24 & $D$ & 14 & & \\
\hline 8 & 35 & LBL & 23 & C & 13 & & \\
\hline$y^{x}$ & 05 & $c$ & 13 & 6 & 06 & & \\
\hline \multirow[t]{2}{*}{1} & 01 & ST0 1 & 3301 & $\bullet$ & 83 & & \\
\hline & & & & & & \multicolumn{2}{|c|}{ Register } \\
\hline • & 83 & 1 & 01 & 8 & 08 & \multirow{10}{*}{$\begin{array}{l}R_{1} V k \\
R_{2}- \\
R_{3}- \\
R_{4}- \\
R_{5}- \\
R_{6}- \\
R_{7}- \\
R_{8}- \\
R_{9}-\end{array}$} & \multirow{2}{*}{ vw adf } \\
\hline 1 & 01 & - & 83 & 9 & 09 & & \\
\hline 2 & 02 & 4 & 04 & 5 & 05 & & 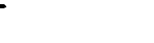 \\
\hline 1 & 01 & 4 & 04 & $x$ & 71 & & \\
\hline 6 & 06 & RSL 1 & 3401 & RTN & 24 & & \\
\hline $\mathrm{x}$ & 71 & 8 & 35 & LBL & 23 & & \\
\hline RTN & 24 & $y^{x}$ & 05 & $E$ & 15 & & \\
\hline LBL & 23 & - & 83 & 6 & 06 & & \\
\hline B & 12 & 0 & 00 & • & 83 & & - \\
\hline A & 11 & 2 & 02 & 8 & 08 & & \\
\hline
\end{tabular}


PROGRAA WE-975-10. PEAK OVERPRESSLRE GIVEA YIELD AND RANGE FOR SURFACE RURST OR FREF AIR BURST

\section{Description}

Thls program combines the analytic approximations given by Brode ${ }^{3}$ for surface bursts and free air bursts. Because no approximations are made in this program, the error discusston in Chapter III of Brode's report npplies.

rield entries are in $H t$, and range is in thousands of feet (kllofeet)

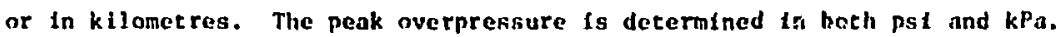

\section{User Instructions}

\begin{tabular}{|c|c|c|c|c|}
\hline Step & $\begin{array}{l}\text { Inst ruce ions / } \\
\text { comments }\end{array}$ & $\begin{array}{c}\text { Input } \\
\text { data/units }\end{array}$ & Key & $\begin{array}{c}\text { Oucput } \\
\text { data/units }\end{array}$ \\
\hline 1 & Enter program. & & & \\
\hline \multirow[t]{3}{*}{2} & Enter $\mathrm{N}$ in $\mathrm{Mt}$. & & & \\
\hline & If surface burst: & $W(M t)$ & $A$ & \\
\hline & If free air burst: & $W(M t)$ & $\mathbf{E}$ & \\
\hline \multirow[t]{3}{*}{3} & Enter $R$ & & & \\
\hline & If $R$ is In kilofeet: & $R(k f t)$ & B & $p(p s 1)$ \\
\hline & If $R$ is in kilometres: & $R(\mathrm{~km})$ & $\mathrm{C}$ & $p(p s i)$ \\
\hline 4 & If $\mathrm{p}$ is wanced in $\mathrm{kPa}$ : & & D & $p(k P a)$ \\
\hline
\end{tabular}

\section{Examples}

We 1ist a few examples in shorthand notation:

Q. What is the peak overpressure from a 5-Mt surface burst at $10000 \mathrm{ft}$ ?

A. 5 A $10 \mathrm{~B}$; read $32.85 \mathrm{psI}$

Q. What is the peak overpressure in psi from a 1-Mt free air burst at $1 \mathrm{~km}$ ?

A. $1 \mathrm{E} 1 \mathrm{C}$; read 73.37 psi.

Q. What is the peak Jverpressure in both psi and kPa $1000 \mathrm{ft}$ from a 1-Mt surface burst?

A. 1 A 1 B; read 3393.40 ps 1

D; read $23397.48 \mathrm{kPa}$. 
Iteration may be used to answer questions such as:

Q. At what distance from a $500-k t$ surfice burst is the neak "verpressure 2 ps1?

A. Try: $0.5 \times 10 \mathrm{~B}$; read $6.99 \mathrm{psI}$

$0.5 \times 20 \mathrm{~B}$; rend $2.13 \mathrm{pel}$

0.5 A 21 R; read $i .97 \mathrm{ps} 1$.

The distance is thus about $21000 \mathrm{ft}$.

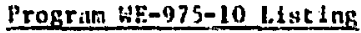

\begin{tabular}{|c|c|c|c|c|c|c|c|c|c|c|}
\hline $\begin{array}{l}\text { key } \\
\text { entry }\end{array}$ & $\begin{array}{l}\text { Code } \\
\text { shown }\end{array}$ & $\begin{array}{l}\text { key } \\
\text { entry }\end{array}$ & & ode & $\begin{array}{l}\text { Key } \\
\text { entry }\end{array}$ & & $\begin{array}{l}\text { ode } \\
\text { own }\end{array}$ & $\begin{array}{l}\text { hey } \\
\text { entr: }\end{array}$ & & $\begin{array}{l}\text { Code } \\
\text { shawn }\end{array}$ \\
\hline LBi & 23 & 5 & & 05 & $x$ & & 71 & сто & & 22 \\
\hline$E$ & 15 & 2 & & 02 & RCL 2 & 34 & 02 & $\mathbf{B}$ & & 12 \\
\hline 2 & 02 & RCL 1 & 34 & 01 & $\vdots$ & & B) & LHL. & & 23 \\
\hline$\div$ & 81 & $x$ & & 71 & + & & 61 & D) & & 14 \\
\hline LBL & 23 & RCl. 2 & 34 & 02 & . & & 83 & 6 & & 06 \\
\hline A & 11 & $t$ & & 41 & 0 & & 00 & - & & 83 \\
\hline 1 & 01 & $x$ & & 71 & 2 & & 02 & $\mathbf{B}$ & & 08 \\
\hline 0 & 00 & $\div$ & & 81 & 1 & & 01 & $\bar{y}$ & & on \\
\hline 0 & 00 & RCL 2 & 34 & 02 & 5 & & 05 & 5 & & 05 \\
\hline 0 & 00 & $\div$ & & 81 & + & & 61 & $x$ & & 71 \\
\hline$x$ & 71 & RCL 1 & 34 & 01 & ST0 3 & 33 & 03 & $\operatorname{RiN}$ & & 24 \\
\hline STO 1 & 3301 & RCL 2 & 34 & 02 & $\mathrm{R} / \mathrm{S}$ & & 84 & \multicolumn{3}{|c|}{ Registers } \\
\hline $\begin{array}{l}\text { RCL } 2 \\
\text { R/S }\end{array}$ & $\begin{array}{r}34 \quad 02 \\
\quad 84\end{array}$ & $\begin{array}{l}\div \\
\mathbf{f}\end{array}$ & & $\begin{array}{l}81 \\
31\end{array}$ & $\begin{array}{l}\text { L.BL } \\
C\end{array}$ & & $\begin{array}{l}23 \\
13\end{array}$ & \multirow{3}{*}{\multicolumn{2}{|c|}{$\begin{array}{ll}R_{1} & \text { Used } \\
R_{2} & \text { Used } \\
R_{3} & \text { Used }\end{array}$}} & \\
\hline LBL & 23 & $\sqrt{x}$ & & 09 & . & & 83 & & & \\
\hline B & 12 & 7 & & 07 & 3 & & 03 & & & \\
\hline STO 2 & 3302 & - & & 83 & 0 & & 00 & $R_{4}$ & - & \\
\hline 3 & 03 & 6 & & 06 & 4 & & 04 & $\mathrm{R}_{S}$ & - & \\
\hline - & 83 & 3 & & 03 & 8 & & 08 & $R_{6}$ & - & \\
\hline 1 & 01 & 3 & & 03 & $\div$ & & B1 & $\begin{array}{l}R_{7} \\
R_{6} \\
R_{9}\end{array}$ & $\begin{array}{l}- \\
- \\
-\end{array}$ & \\
\hline
\end{tabular}


PROKRAM WF-975-11. PEAK OVERPRESSURE TOJFROM VN adj

\section{Description}

This propram determinus the pak overpressure $p$, ordinarily interpeated It: that pressure associated with 537 probabllity of damage $\left(p_{0.5}\right.$ of Ref. 1$)$,

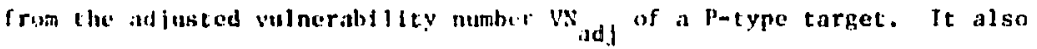
performs the reverse calculation: determining wa from the peak nuerpressure. Elther conventomal or Sl unlts of pressure may be used or determined in the ialculations.

\section{User Instructions}

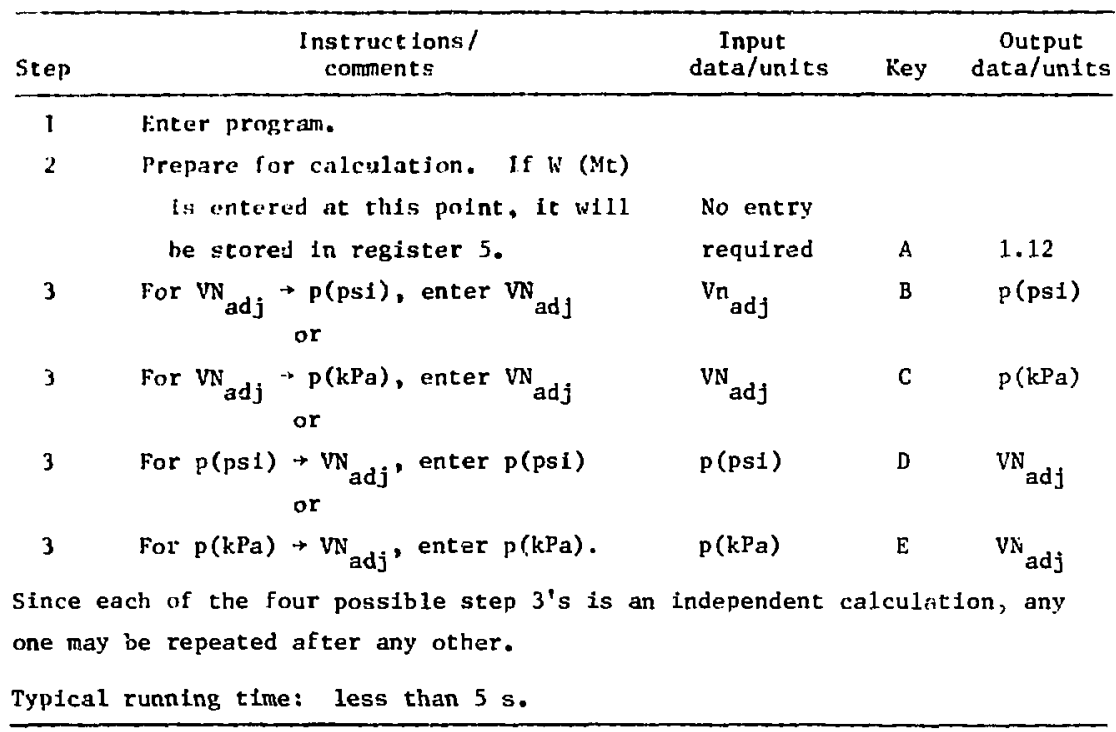

\section{Examples}

We use a "shorthand" notation to illustrate uses of the program:

Q. What is $\mathrm{p}$ (psi) if $\mathrm{VN}$ adj is 28 ?

A. Enter: $(\Lambda) 28 \mathrm{~B}$; read $\mathrm{p}=184.89 \mathrm{ps}$.

The parentheses around A Indicate that LBL A must be keyed in once only and does not necessarily have to be keyed in for subsequent calculations. 
Q. What is $\mathrm{VN}_{\text {adj }}$ for a 1000-ps1 target?

A. Th:is is a sloppy question. We assume 1 means "What is $\mathrm{VN}$ adj if $\mathrm{p}_{0.5}$ is 1000 psi?"

Enter $1000 \mathrm{D}$; read $V n_{a d j}=3726$. If no previous calculation has been made enter A $1000 \mathrm{D}$; read $\mathrm{VN}_{\mathrm{ac}}=37.26$.

Q. What is $\mathrm{VN}_{s d \mathrm{~d}}$ if $\mathrm{P}_{0.5}$ 1s $7000 \mathrm{kPe}$. for a 500-kt surface burst with a 10C0 if CEP?

A. If the intent is to go on to a calcuiation of $p_{k}$ using WE-975-4, it is better to get $W$ stored before calculating W adf. Remember that $W$ is entered in Mt: Enter 0.5 A $7000 \mathrm{E}$; read $\mathrm{VN}_{\text {adj }}=37.34$. The calculator is now ready to accept WE-975-4.

Q. What is $p(\mathrm{kPa})$ if $\mathrm{N}_{\text {adj }}$ is 12 ?

A. Enter $12 \mathrm{C}$; read $\mathrm{p}_{0.5}=68.95 \mathrm{kPa}$, 
Program WE-975-11 List1ng

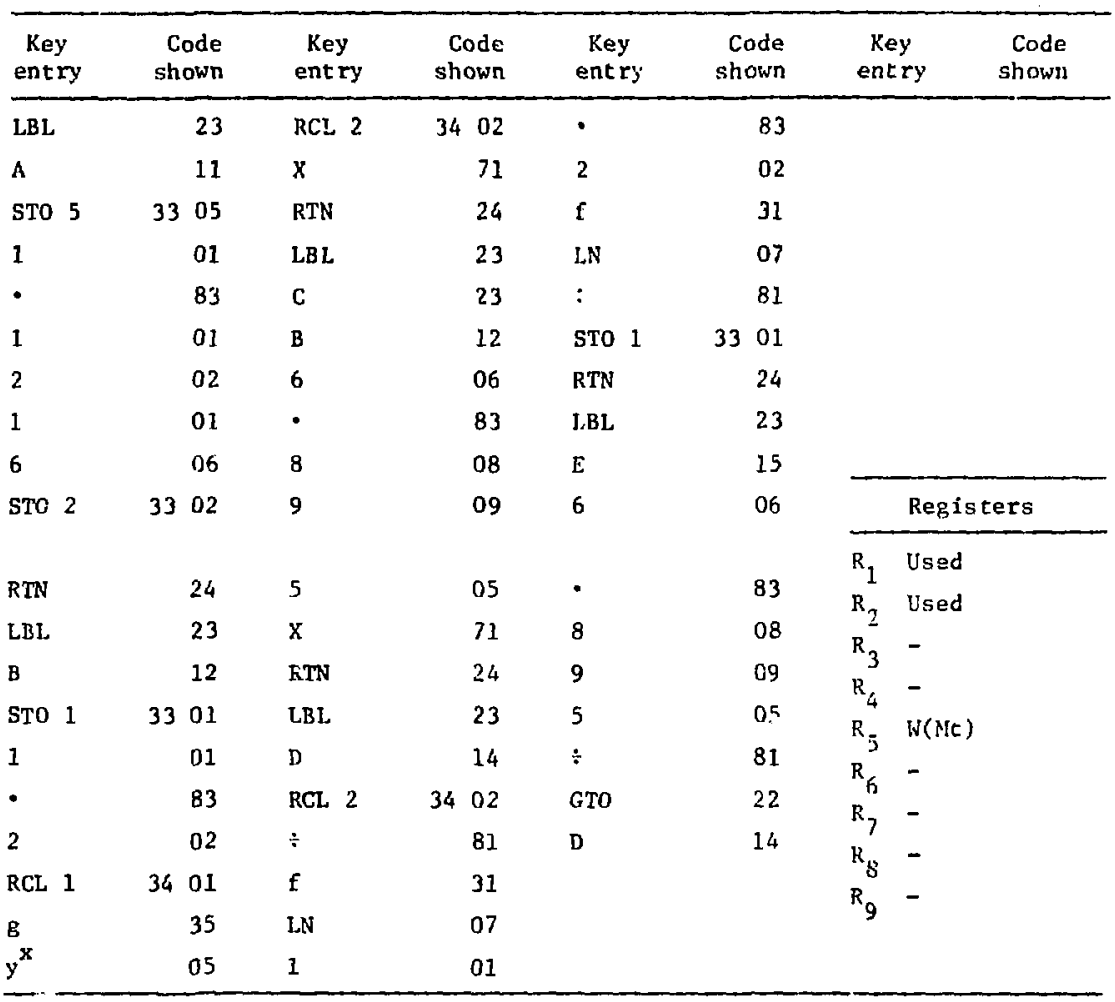




\section{Description}

This program determines the peak dynamic pressure c, ordinarily interpreted as that pressure associated with $50 \%$ probability of damage $\left(q_{0.5}\right.$ of Ref. 1), from the adjusted vulnerability number $V_{\text {adj }}$ of a Q-type target. It also performs the reverse calculation: detetmining $\mathrm{WN}_{\text {adj }}$ from the peak dynamic pressure. Elther conventional or SI units may le used or determined In the calculations.

\section{User Instructions}

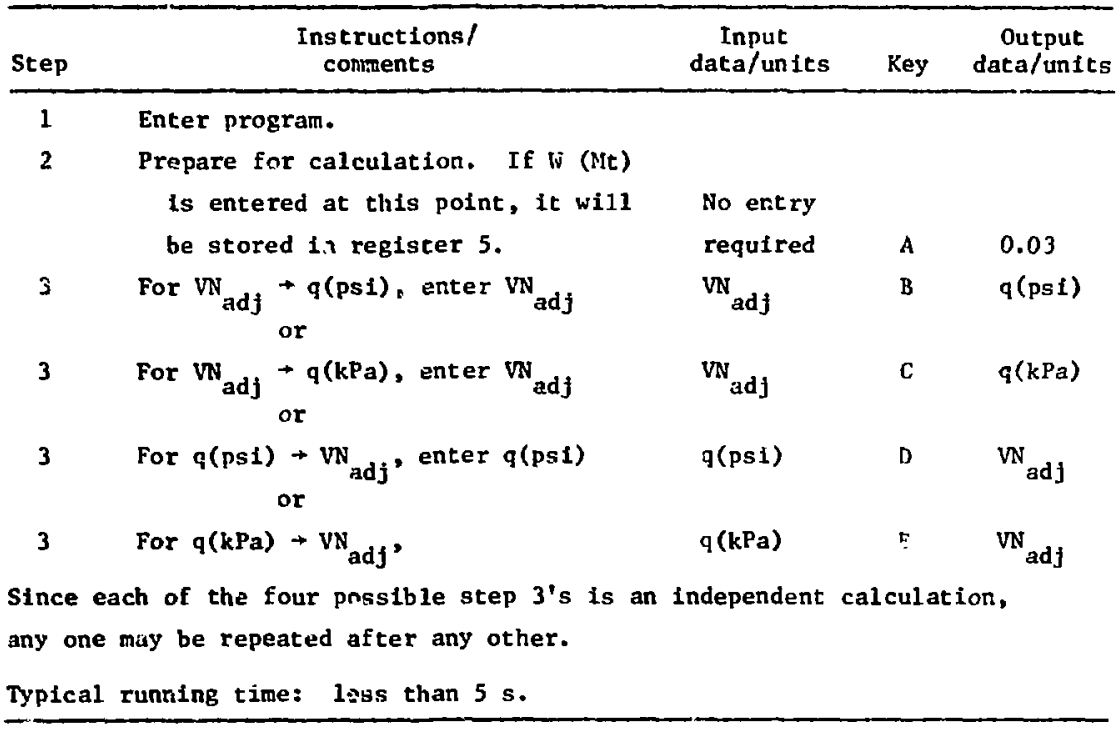

\section{Examples}

We use a "shorthand" notation to 1llustrate uses of the program:

Q. Whac is $q$ (psi) if $\mathrm{VN}_{\text {adj }}$ is 28 ?

A. Encer (A) $28 \mathrm{~B}$; read $q_{0.5}=786.14 \mathrm{psi}$.

The parentheses around $A$ indicate that LBL $A$ must be keyed in once only and does not necessarily have to be keyed in for subsequent calculations. 
Q. What is $\mathrm{VN}_{\text {adj }}$ for a 1000-psi target?

A. I'his is a sloppy question. We assume it means "What is $\mathrm{nN}_{\text {adj }}$ if $q_{0.5}$ is 1000 psi?" Enter $1000 \mathrm{D}$; read $\mathrm{VN}_{\text {adj }}=28.66$ if no previous calculations has been
made

Enter A $1000 \mathrm{D}$; read $\mathrm{WN}_{\text {adj }}=28.66$.

Q. What is $\mathrm{VN}_{\text {adj }}$ if $\mathrm{q}_{0.5}$ is $7000 \mathrm{kPa}$ for a $500-\mathrm{kt}$ surface burst with a 1000- $\mathrm{r}$ CEP?

A. If the intent is to go on to a calculation of $P_{k}$ usfing WE-975-8, it is better to get $W$ stored before calculating $\mathrm{VN}_{\text {adj. }}$. Remember that $\mathrm{W}$ is entered in Mt: Enter $0.5 \wedge 7000 \mathrm{E}$; read $\mathrm{VN}_{\mathrm{adj}}=28.70$. The calculator is now ready to accept $\mathrm{WE}-975-8$.

Q. What is $q(\mathrm{kPa})$ if $\mathrm{VN}_{\text {adj }}$ is 12 ?

A. Enter $12 \mathrm{C}$; read $\mathrm{q}=15.86 \mathrm{kPa}$. 
Program WE-975-12 Listing

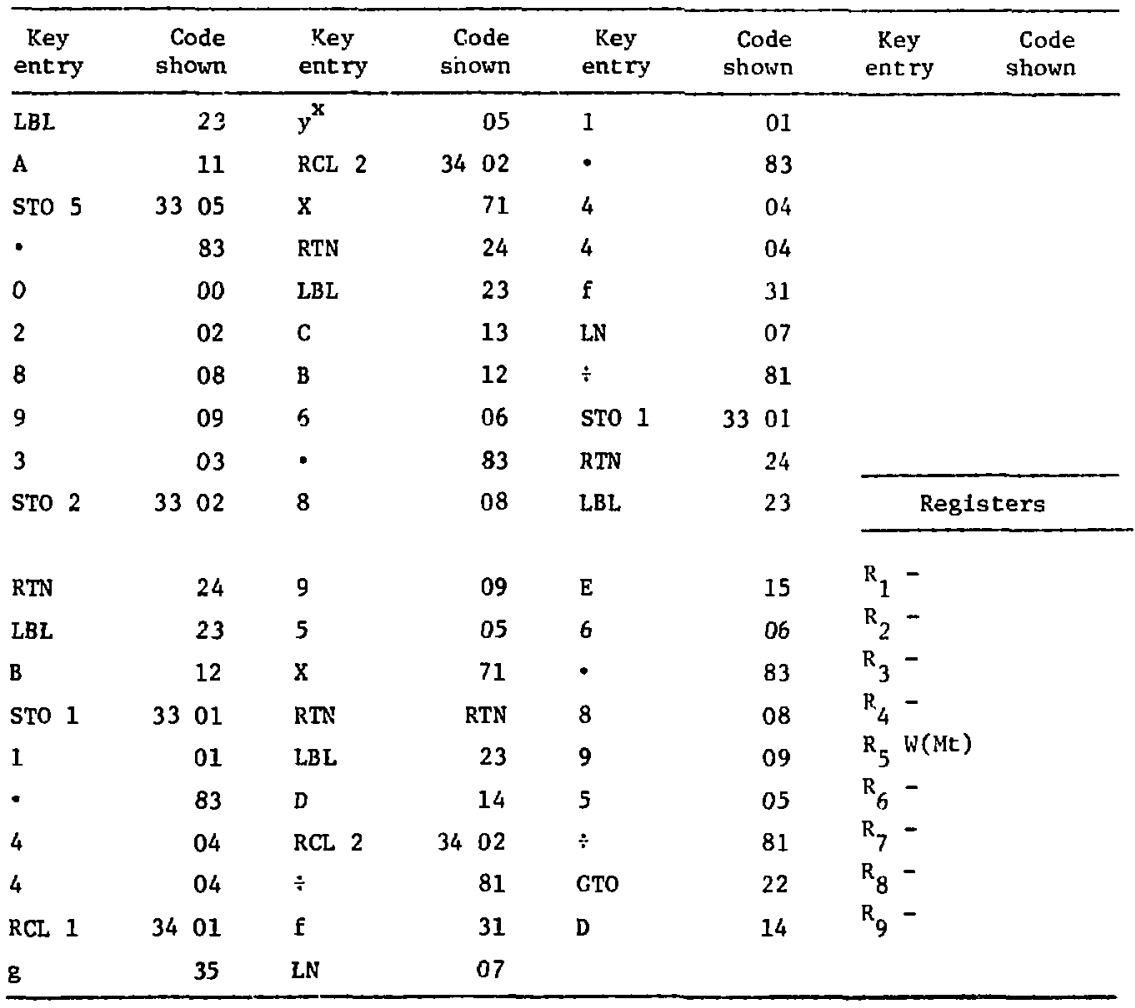




\section{References}

1. Physical Vulnerability Handbook - Nuclear Weapons, Defense Intelligence Agency, Washington, D.C., Rept. AP-550-1-2-INT (1969; with changes, 1974) (title $U$, report $C$ ). The material pertinent to this report is also Included in two unclassified reports: Mathematical Background and Programming Aids for the Physioal Vulnerability Syatem for Muclear Weapons, Defense Intelligence Agency, Rept, DI-550-27-74 (1974); KiZl Probability and the Related Analysis for Blast-Type Targets, TRW Systems Group, Redondo Beach, Calif., TRW Sales No. 23942 (1974).

2. 0 . J. Loper and W. A. Barletta, Lawrence Livermore Laboratory, private communication, (1975).

3. H. L. Brode, Height of Burst Effects at High Overpressurea, RAND Corp., Santa Monica, Calif., Rept. DASA-2506 or RM-6301-DASA (1970). 